University of Wollongong

Research Online

Faculty of Business - Papers (Archive)

Faculty of Business and Law

$1-1-2014$

Does banks' dual holding affect bank lending and firms' investment decisions? Evidence from China

Xiaofei Pan

University of Wollongong, xpan@uow.edu.au

Gary Tian

University of Wollongong, gtian@uow.edu.au

Follow this and additional works at: https://ro.uow.edu.au/buspapers

Part of the Business Commons

Research Online is the open access institutional repository for the University of Wollongong. For further information contact the UOW Library: research-pubs@uow.edu.au 


\title{
Does banks' dual holding affect bank lending and firms' investment decisions? Evidence from China
}

\begin{abstract}
This study investigates the effect of banks' dual holding on bank lending and firms' investment decisions using a sample of listed firms in China. We find that dual holding leads to easier access to bank loans, a result that is more pronounced for non-state-owned enterprises (non-SOEs) than SOEs. We also find that dual holding distorts banks' lending decisions and harms the investment efficiency for SOEs, while resulting in optimal lending decisions and enhanced investment efficiency for non-SOEs. For non-SOEs, further analysis suggests that optimal lending decisions and efficient investment can be achieved for firms with higher ownership concentration, and firms in which the family and foreign investors are the controlling shareholders. We argue that, in emerging markets, whether a bank plays a monitoring role by directly holding the debt and equity claims of companies relies heavily on whether the potential collusion between firm executives and bank managers can be averted, which in turn is determined by the firms' governance framework and ownership structure.
\end{abstract}

\section{Keywords}

firms, investment, decisions, affect, holding, dual, evidence, banks, china, does, bank, lending

\section{Disciplines \\ Business}

\section{Publication Details}

Pan, X. \& Tian, G. Gang. (2015). Does banks' dual holding affect bank lending and firms' investment decisions? Evidence from China. Journal of Banking and Finance, 55 406-424. 


\title{
Does banks' dual holding affect bank lending and firms' investment decisions? Evidence from China
}

Xiaofei Pan, School of Accounting and Finance, University of Wollongong

Gary Tian*, School of Accounting and Finance, University of Wollongong

\begin{abstract}
This study investigates the effect of banks' dual holding on bank lending and firms' investment decisions using a sample of listed firms in China. We find that dual holding leads to easier access to bank loans, a result that is more pronounced for non-state-owned enterprises (non-SOEs) than SOEs. We also find that dual holding distorts banks' lending decisions and harms the investment efficiency for SOEs, while resulting in optimal lending decisions and enhanced investment efficiency for non-SOEs. For non-SOEs, further analysis suggests that optimal lending decisions and efficient investment can be achieved for firms with higher ownership concentration, and firms in which the family and foreign investors are the controlling shareholders. We argue that, in emerging markets, whether a bank plays a monitoring role by directly holding the debt and equity claims of companies relies heavily on whether the potential collusion between firm executives and bank managers can be averted, which in turn is determined by the firms’ governance framework and ownership structure.
\end{abstract}

Key words: Bank dual holding, Lending decision, Investment efficiency, SOEs and nonSOEs, Conflicts of interest, China

JEL: G31, G34, G21

\footnotetext{
* Gary Tian (email address gtian@uow.edu.au) is corresponding author. Xiaofei Pan’s email address is xpan@uow.edu.au. The authors are grateful to the valuable comments by anonymous referees and the suggestions by Professor Ike Mathur (the Editor). We also thank the valuable comments received from discussants and participants of the 26th Australasian Finance \& Banking Conference, Sydney, Australia, held in December, 2013.
} 


\section{Introduction}

A large body of literature argues that banks are able to provide more efficient debtrelated external monitoring for the corporate governance of firms because they have a comparative cost advantage in accessing superior inside information (Fama, 1985; Datta et al., 1999). But what happens if banks as creditors also hold equity in the same firm (dual holding)?

Recent investigations have focused on this phenomenon and its financial implications for the corporate governance system, albeit with mixed results. Some studies from developed markets agree that dual holding can help to internalize the conflicts of interest between shareholders and creditors and to obtain proprietary information about the firm due to dual holders' involvement on both the debt and equity sides. Thus, these studies find that dual holding can benefit firms by promoting their access to bank capital and improving their performance (Kang et al., 2000; Mahrt-Smith, 2006; Jiang et al., 2010). Meanwhile, another strand of studies focuses on the harmful effects of dual holding, arguing that it leads to potentially more serious conflicts of interest (Diamond, 1984; Welch, 1997). Empirical evidence suggests that, although dual holdings allow firms in emerging markets to have better access to debt financing, banks do not monitor these firms quite so extensively, which may result in poorer firm performance (Lin et al., 2009; Luo et al., 2011).

The literature also documents that in emerging markets, where the banks are the main providers of capital and bank credit is scarce and highly regulated by the government (Cull and $\mathrm{Xu}, 2000$ ), bank lending may increase the probability that borrowers will collude with bank managers. This in turn encourages borrowers to seek rents through bribing bank managers. However, the existing empirical results concerning the effect of corruption are mixed. Cai et al. (2011) find that bribing officials reduces firm performance, while Chen et al. (2013) argue that corruption can improve banks' lending decisions and aid private firms in China. These studies provide no evidence for whether corruption prevents dual holders from playing a monitoring role, and thus from contributing to improved firm performance.

In addition to the ambiguous findings from studies of the financial and economic implications of dual holding, there is no comprehensive analysis showing the mechanism through which dual holding works, especially in emerging markets. In this paper we attempt to address the interesting and unresolved question of the role that banks' dual holding has played, what are its related costs and benefits, and how it influences firm performance, given that corruption in the banking industry is prevalent in emerging markets. 
To achieve a better understanding of the role of banks' dual holding in corporate performance in emerging markets, we first examine the effect of dual holding on firms' access to bank loans, and then explore the channel(s) through which dual holding affects firm performance by investigating its effect on banks' lending decisions and firms' investment efficiency. The existing literature finds that optimal bank lending reinforces firms' investment efficiency, while politically based soft lending may bias firms' behaviour with regard to investment decisions (Lang et al., 1996; Chen et al., 2011). Firms' investment decisions thus significantly influence firm performance, because firm performance responds positively to better investment, and gains from investments enhance firm profitability (Fama and French, 1998; Chen et al., 2009). Since dual holding facilitates the flow of capital and promotes companies' access to bank capital (Kang and Shivdasani, 1995; Lin et al., 2009), we expect dual holding will affect firm performance through its influence on banks' lending decisions and firms' investment policy.

In developed countries, permitting banks to hold equity in non-financial companies can mitigate the conflicts of interest between shareholders and creditors that create incentives to deviate from optimal investment ${ }^{1}$ (Kang et al., 2000; Kroszner and Strahan, 2001). Nevertheless, in emerging markets, where there is often strong government intervention and prevalent corruption in the banking sector, existing evidence suggests that banks are reluctant to be effective monitors (Barth et al., 2006), and state-owned banks are obliged to lend largely to SOEs to maintain normal economic growth and achieve social goals (Cull and $\mathrm{Xu}$, 2005; Allen et al., 2005). On the other hand, banks' dual holding may also lead to potential collusion between banks' and borrowers' managers, who often pursue empire-building and other private benefits. This collusion leads to connection-based soft lending decisions, which results in inefficient investment by borrowers and further destroys firm value. Therefore, it is the net effect of banks' dual holding, between the benefits of accessing bank loans and the costs of collusion, that will determine banks' lending and firms' investment decisions.

While banks' dual holding of non-financial companies is not unique to China, the Chinese corporate and financial environment is particularly interesting for this research because China is the largest transition economy, and is characterized as having an absence of mature public bond markets. Indeed, corporate external finance relies mostly on bank borrowing, so banks play a very important role in determining the availability of credit. In

\footnotetext{
${ }^{1}$ The asset-substitution problem (Jensen and Meckling, 1976), the underinvestment problem (Myers, 1977), and the overinvestment problem (Stulz, 1990) are well-known examples of such distortions of investment policy.
} 
addition, the Chinese financial system is dominated by the government through direct and indirect state ownership and control of most banks, while these banks' lending decisions often reflect government-dictated policies (Firth et al., 2009; Chen et al., 2013). In other words, state-owned banks dominate the Chinese financial system, and tend to allocate and price loans according to government preferences.

Second, the co-existence of state-owned enterprises (SOEs) and non-SOEs in China provides another unique institutional environment in which to examine the effects of dual holding on banks' lending decisions and borrowers' investment efficiencies and, in turn, on the performance of firms with different ownership. From the banks' perspective, because state-owned banks wish to achieve multiple objectives, including their political and economic goals, they tend to lend largely to SOEs and bail out poorly performing SOEs; thus they can largely ignore SOEs' non-performing loans, a typical soft lending decision (Cull and $\mathrm{Xu}$, 2003; Firth et al., 2008). Moreover, SOEs have a multilayered principal-agent framework and inadequate ultimate property-rights protection, which may further increase the chance of collusion between managers of borrowers and banks when banks have dual holdings in SOEs, due to lack of sufficient monitoring by the state controlling shareholder. In contrast, banks are required to extend their discipline and monitoring to the non-SOEs they lend to (Santos and Rumble, 2006), and are eager to maximize their proceeds by advocating effective monitoring on firms' investments. From the borrowers' perspective, non-SOEs are similar to their counterparts in developed markets in that they have a simpler objective of value maximization (Chen et al., 2011), and thus the potential collusion between managers of firms and banks can be averted by the controlling shareholders. Therefore, the homogeneity of state ownership in both banks and SOEs and the heterogeneity of ownership structure between SOEs and non-SOEs make China an excellent context in which to examine the effect of banks' dual holding on their lending decisions and firms' investment policy across SOEs and non-SOEs.

Furthermore, the unique Chinese institutional setting for banks' dual holding also allows us to further reduce concerns about an endogeneity issue. Although the Commercial Bank Law implemented in 1995 did not force banks to relinquish their existing ownership in listed non-financial firms, banks have not been allowed to invest any new equity in non-financial firms since then. Therefore, banks' dual holding during our sample period (2003 to 2010) was largely exogenously determined and less likely to be affected by firm characteristics and corporate governance variables. This is perhaps the most significant advantage of using Chinese data: it allows us to infer the nature of banks' dual holding when its formation 
predates, by several years, the lending decisions and firm investment policies we wish to analyse. We argue that such a lag between the formation of banks' dual holding, their lending decisions and firms' investment policies removes concerns about reverse causality. Nevertheless, we will also apply alternative approaches to dealing with the potential endogeneity issue, including event-study methodology, natural experiment, and two-stage least square and fixed-effect regressions.

From the empirical analysis we find that the change in the ratio of bank loan to total assets is higher when a borrower's lender (a bank) is among the borrower's top ten largest shareholders (dual holding). This effect is more pronounced in non-SOEs than SOEs. We also find that dual holding reinforces the exercise of using commercial judgments in allocating capital to non-SOEs, which is consistent with previous studies (Firth et al., 2009; Chen et al., 2013), while dual holding is more likely to distort banks' lending decisions and lead to capital misallocation to SOEs. We further find that dual holding is likely to enhance investment efficiency only in non-SOEs, whereas dual holding in SOEs relates to a less efficient investment. Our results also suggest that for non-SOEs, shareholders with more highly concentrated ownership, or family and foreign controlling shareholders are more able to exert effective monitoring on the collusion between the managers of firms and banks, which leads to optimal lending decisions and more efficient investment than for other nonSOEs.

Our findings also confirm that dual holding is less likely to add value for SOEs, which is consistent with the evidence from other emerging markets (Fok et al., 2004; Lin et al., 2009), while dual holding is more likely to increase value for non-SOEs, which is similar to what occurs in developed markets. Our investigation complements the notion that dual holding can be a double-edged sword in emerging markets. We argue that whether a bank plays a monitoring role by directly holding the debt and equity claims of companies relies heavily on whether the potential collusion between managers of firms and banks can be averted, which in turn is determined by the governance framework and firms’ ownership structure. Our main findings are robust to corrections for the endogeneity of dual holding, including using single bank loan contracts, event studies of loan contracts and mergers and acquisitions announcements, natural experiments regarding the release of an economic stimulus package, and two-stage least square and fixed-effect regressions.

This study contributes to the existing literature in several ways. First, the relationship between banks and firms through dual holding, and its consequences for firm performance and valuation, has recently evolved, but with mixed evidence. Our research adds new 
evidence to the literature concerning the effect of dual holding in emerging markets. Existing studies focus more on matured markets ${ }^{2}$; little is known about how dual holding works to affect firm performance and its effect in emerging markets. We propose that bank lending and firm investment are the channels through which dual holding can affect firm performance, so we argue that whether dual holding can increase firm value depends heavily on how effectively banks' lending decisions and firms' investment decisions are monitored. Existing literature documents that how banks monitor a borrower depends on the severity of the agency problems between creditors and borrowers (Harvey et al., 2004); our evidence adds new insight by suggesting that in emerging markets where property rights are not clearly defined, the degree to which banks play their monitoring role through directly holding firms' equity depends on the severity of the agency problems between managers and shareholders of borrowing firms.

Second, an evolving literature relating to dual holding has recently begun to focus on China (Lin et al., 2009; Luo et al., 2011). Lin et al. (2009) find that bank ownership increases the tendency for companies to bank capital access, but reduces operating performance because the monitoring of the firms' investment is compromised; Luo et al. (2011) examine the way bank ownership affects firm performance through corporate executive perquisites (perks). In a departure from these papers, the current study provides direct evidence of the effect of dual holding on banks' lending decisions and firms' investment policies. We argue that an optimal lending decision leads to investment efficiency for borrowers, and the effect of dual holding is determined by firms' ownership structure. Moreover, unlike prior studies, which use a pooled sample of all listed firms with only a dummy to control for the effect of SOEs, this study completely disentangles the effect of dual holdings between SOEs and nonSOEs by considering them independently. Our study provides fresh evidence that dual holding is likely to enhance banks' lending decisions and firms' investment efficiency only in non-SOEs, while the opposite holds for SOEs. On that basis, this study provides much more robust and comprehensive evidence for the effect of dual holding on firm performance in an emerging market, particularly in an environment where state ownership dominates the financial system.

Third, we complement a growing literature relating to the bank-firm relationship that suggests a few proxies for this relationship, such as relationship banking (Boot, 2000;

\footnotetext{
${ }^{2}$ Most of these studies are from Germany and Japan. Because U.S. regulations prevent banks from holding an equity position in non-financial firms, Jiang et al. (2010) investigate the role of non-commercial banking institutions as dual holders.
} 
Bharath et al., 2011), pre-existing borrower-lender personal relationship (Engelberg et al., 2012), holding bank ownership (Berger et al., 2009) and the appointment of bankers onto the board (Krosnzer and Strahan, 2001; Byrd and Mizruchi, 2005). This study, however, extends our understanding of banks' impact on firms' corporate decisions from a more direct perspective: banks' dual holding of listed companies. We document that the degree to which banks play their monitoring role through directly holding firms' equity depends on the severity of the agency problems between managers and shareholders of borrowing firms.

The remainder of the paper is organized as follows: Section 2 reviews the evolution of banks' dual holding and the economic stimulus package exercised in China, and develops our main hypotheses; Section 3 describes the data and methodology; Section 4 reports our empirical evidence; and Section 5 concludes.

\section{Institutional background and hypothesis development}

\subsection{Banks' dual holding in China}

Beginning in the late 1970s, the Chinese government launched a reform of its banking industry $^{3}$. In the early 1980s, the government established four wholly state-owned banks (the Big Four), which took control of all the commercial banking functions of the People's Bank of China (the Central Bank). In 1994, three wholly state-owned policy banks ${ }^{4}$ were established and took over the policy-lending functions from the Big Four, and it was from that time that joint stock commercial banks and city banks began to emerge in China. Because China lacked a public bond market and relied heavily on bank borrowing, during the early 1990s these banks were the only type of financial institutions in the market, and thus were actively involved in providing capital for corporate sector growth, but under supervision from the People's Bank of China.

In the early 1990s, two stock exchanges were established in Shanghai and Shenzhen, and subsequently many SOEs undertook reform to become listed on one or the other. According to the regulations of the Central Bank, commercial banks were encouraged to participate in the sponsorship and underwriting business of initial public offerings (IPOs) of listed SOEs (Cao, 2008), to become initial shareholders of these IPO firms. In this sense banks' dual holdings were formed before these listed firms began to trade publicly. In 1995 the Commercial Bank Law (revised in 2003) clearly prohibited commercial banks from holding new ownership in non-financial companies without permission from the authorities.

\footnotetext{
${ }^{3}$ During this period, China also initiated economic reform aimed at transforming its economy from planned to market-oriented.

${ }^{4}$ These are the State Development Banks, the Agricultural Development Bank of China, and the Export and Import Bank of China.
} 
The law not only prohibited banks from holding equity in listed firms, it also prevented commercial banks from becoming shareholders of listed firms through other channels, such as becoming the legal personal shareholders of firms that defaulted on their loans, or through a debt-for-equity swap. Although banks can no longer become shareholders of listed companies through direct investment, it is worth noting that they can still exert an active influence through their existing dual holding of the companies (Luo et al., 2011).

\subsection{Economic stimulus package}

Since the global financial crisis of 2007, developing countries have directly injected money into state-controlled banks to stimulate economic growth, which has resulted in a significant credit growth since 2008 in large emerging markets like India, China, Turkey, and Brazil (Onaran, 2013). In China, between the end of 2008 and 2010, 4 trillion RMB (about $\$ 586$ billion), which accounted for $12.5 \%$ of total GDP in 2008, was injected into public projects. Following the application of several instruments to boost bank-loan supply, it substantially increased between the fourth quarter in 2008 and the fourth quarter in 2010, due to the stimulus program (Shen et al., 2014).

The government's intention to increase its funding to small- and medium-sized enterprises from bank loans was manifested in the People’s Bank of China's stated monetary policy "to guide financial institutions to increase credit lending to agriculture, rural areas and farmers, small- and medium-sized enterprises”. However, as argued by Shen et al. (2014), small and private firms are still limited in their access to bank lending because of information asymmetry, while state-owned banks would choose more reliable companies as clients. They found that the expanded availability of bank loans during 2009 and 2010 does not increase corporate leverage in small and private firms as much as in large and state-owned firms. The question we address is the effect of the implementation of the economic stimulus package on banks' lending decisions and firms' investment efficiency across SOEs and non-SOEs. This natural experiment provides us with an opportunity to test whether SOEs with banks as dual holders are more sensitive to the exogenous shocks of bank loan supply than those without dual holders, which results in loan decisions being less optimal in these SOEs; and whether the situation in non-SOEs is the exact opposite. These induced loan incentive changes should lead to changes in firms' investment behaviour and efficiency. We therefore use the dummy Stimulus for the period between 2009 and 2010 to measure the exogenous shock of bank loan supply. Findings about the effect of the stimulus package's implementation will provide us with evidence on how government intervention affects lending decisions and firms' investment policies, which will enable us to add new evidence to the literature. 


\subsection{Hypothesis development}

Our first hypothesis relates to the fundamental effect of dual holding with regard to firms' access to bank loans, especially the potential difference between SOEs and non-SOEs. In principle, the conflicts of interest and information asymmetry between shareholders and creditors could be mitigated when banks are also the shareholders of the same firms (Kroszner and Strahan, 2001); the mitigation of these conflicts could lead to easier access to bank loans (Kang and Shivdasani, 1995; Barth et al., 2006; Lin et al., 2009) and lower cost of loans (Jiang et al., 2010). China is identified as having an underdeveloped financial system and lacking a public bond market; banks are the main providers of capital, while bank credit is scarce (Cull and Xu, 2000; Firth et al., 2008). In addition, more than $90 \%$ of the banking assets in China are owned and controlled by the government, the financial system is dominated by government ownership, and most firm borrowings are supported by bank loans (Firth et al., 2012). Because of this government domination and the policy factors and homogeneity of state ownership, state-owned banks are more likely to grant credit to SOEs than to non-SOEs, following the objectives set by politicians and bureaucrats, to serve both political and economic goals (Firth et al., 2009). As a consequence, non-SOEs face more severe conflicts of interest between creditors and borrowers, as well as more asymmetric information than their SOE counterparts, because non-SOEs have no implicit government guarantee and have shorter bank-borrower relationships than SOEs (Firth et al., 2009). Thus, we expect that the effects of dual holding on reducing conflicts of interest and information asymmetry, and in turn promoting firms to access bank loans, will be more pronounced in non-SOEs than SOEs. Furthermore, the reduction in conflicts of interest and asymmetric information leads to lower monitoring costs, which in turn encourages banks to grant more long-term loans (Guedes and Opler, 1996); thus we also expect that dual holding may lead to more long-term bank loans, a situation that is more pronounced in non-SOEs. Therefore, we construct our first hypothesis as follows:

H1: Dual holding leads to firms having better access to (long-term) bank loans, which is more pronounced for non-SOEs than SOEs.

Our next hypothesis relates to the effects of banks' dual holding on banks' lending decisions and firms' investment decisions. As discussed above, banks' dual holding may lead to potential collusion between banks' and borrowers' managers, who pursue empire-building and other private benefits. This collusion tends to distort bank lending decisions, which results in inefficient investment decisions by borrowers and further destroys firm value. Therefore, it is the net effect of banks' dual holding, between the marginal benefits of 
accessing more bank loans and the marginal costs of collusion, that determines banks' lending decisions and firms' investment decisions.

SOEs' banking relationship has already been established because both banks and firms are owned by the state. If banks have now become shareholders of SOEs, banks' dual holding does not provide additional benefits in terms of accessing bank loans. Nevertheless, it does indicate a better and more stable bank-firm relationship, and these SOEs are now more favoured by state-owned banks. This may eventually lead to a more inefficient allocation of capital because these SOEs are more likely to get bank loans regardless of their profitability and creditworthiness (Zheng and Zhu, 2013). On the other hand, SOEs have a specific corporate governance model with a multilayered principal-agent framework and an unclear clarification of ultimate property rights. Central and local government officials serving as principals hold the control rights in the name of the state without any residual claim rights. Thus, no one in the principal-agent relationship chain has any incentive to maximise profits for the ultimate real principal, while they may have a strong incentive to pursue their own benefits without being adequately monitored by controlling shareholders. This creates the potential for collusion between banks' and firms' managers, along with more severe agency problems in SOEs. As a result, banks' dual holding would suggest a more severe soft lending decision in these SOEs.

Soft lending then encourages SOEs with dual holding to invest more into building their empires, regardless of whether they have good investment opportunities; this reduces their investment efficiency (Firth et al., 2008; Lin et al., 2009). In this sense we conjecture that dual holding reduces the monitoring of firm investment, which results in less efficient investment for SOEs because dual holding increases the chance of collusion between banks' and firms' managers, who tend in this situation to pursue empire building rather than maximize value. Therefore, we expect that the marginal costs of this dual holding dominate the marginal benefits in SOEs, which distorts banks' lending decisions and investment efficiencies. Although the borrowers' inefficient investment may eventually reduce the equity claims from the dual holders, who suffer further deterioration in their lending efficiency and increases in their bad debt level, bank managers will not change the corrupt behaviour of their suboptimal lending decisions because they tend to maximize their private benefit while they do not (fully) account for banks' losses from their lending.

However, non-SOE listed firms have evolved since 2001 and are now comparable in many ways to their counterparts in developed economies, where value maximization is the dominating objective (Allen et al., 2005; Chen et al., 2011). In particular, the property rights 
of non-SOEs in China are naturally personal or family-based, which is similar to firms in the west, resulting in a better aligned principal-agent relationship. Therefore, the controlling shareholders, who are endowed with better monitoring capabilities, are able to prevent managers from colluding with bank managers through their effective monitoring. Moreover, as banks are more likely to allocate capital to financially healthier non-SOEs using commercial judgments (Firth et al., 2009; Chen et al., 2013), and as dual holders are better informed and have access to more inside information, which can help banks to evaluate these non-SOEs more accurately, we expect that banks' dual holding leads to optimal lending decisions towards non-SOEs. In addition, since dual holding may effectively alleviate agency problems between creditors and borrowers (Kroszner and Strahan, 2001; Jiang et al., 2010), the dual holder of a non-SOE is likely to extend monitoring on investment decisions to safeguard its own interest of liability quality, because the potential collusion between banks' and firms' managers is averted. This in turn results in more efficient investment of capital for non-SOEs. Thus, the marginal benefits of dual holding prevail among non-SOEs, which may lead to optimal bank lending decisions and efficient investment. Therefore, we have the following hypotheses:

H2a: Dual holding distorts banks' lending decisions for SOEs, while it improves banks' lending decisions for non-SOEs.

H2b: Dual holding reduces investment efficiency for SOEs while it enhances investment efficiency for non-SOEs.

To extend our collusion story by providing direct evidence on how the potential collusion between managers of firms and banks is averted, we further examine how ownership structure (ownership concentration and owner type) affects the relationship between dual holding, lending decisions and investment efficiencies in non-SOEs. Shleifer and Vishny (1986) show that some degree of ownership concentration enhances firm performance because large block shareholders, in a position to harvest a substantial portion of the gains from improvement in firm performance or a takeover, have some incentive and resources to monitor management decisions. Using the sample of China's listed firms, Qi et al. (2000) find that firm performance is positively related to the proportion of legal-person shares. Therefore, we conjecture that the largest shareholders of firms with higher concentrated ownership are able to exert monitoring.

Additionally, there is normally a controlling shareholder for non-SOEs other than the state, which can be a family or an institutional or foreign investor. These controlling shareholders may monitor managers to avert their collusion with bank managers, as 
concentrated ownership can reduce managerial opportunism and expropriation (Wei et al., 2005). Most non-SOEs are controlled by either a family or an individual, with the remainder controlled by foreign, institutional, and collective investors. The literature shows that in family-controlled firms, the controlling families are more likely to appoint family members or friends as managers, and have a strong incentive to exercise active monitoring of management (Wang, 2012). Other studies also find that active monitoring of management can be also exercised by institutional shareholders (Almazan et al., 2005; Zeng et al., 2011) and foreign investors (Douma et al., 2006; Firth et al., 2006), which is difficult for smaller or lessinformed investors. However, short-termism and the low stake of institutional holding in listed firms in China discourage these institutional investors from taking action to effectively monitor the management (Chen et al., 2007). Therefore, we conjecture that family and foreign investors are more able to exert effective monitoring on the collusion between managers of firms and banks, which will lead to optimal lending decisions and more efficient investment than in firms with other controlling shareholders. We construct our last hypothesis as follows:

H3: Dual holding in non-SOEs results in optimal lending decisions and efficient investment for firms with higher ownership concentration and firms with family investors and foreign investors as the controlling shareholders.

\section{Sample selection and methodology}

\subsection{Sample selection}

Our sample data are obtained from the Chinese Stock and Market Accounting Research database (CSMAR) from 2003 to 2010 for all the listed firms on the Shanghai and Shenzhen stock exchanges. We start our sample from 2003 because the new accounting and auditing standards were applied in 2002, and we collect a total population of 8,496 firm-year observations. Following common practice, we delete the 190 firm-year observations of firms from the financial industry and the 373 firm-year observations of firms flagged with ST or ST*. We also exclude 227 firm-year observations with missing information on the variables that are used in this study. In addition, to be consistent with our theoretical argument, the treatment of firms we are interested in should be those where banks are both shareholders and creditors. Thus, to ensure the accuracy of our empirical analysis, we further exclude 135 firm-year observations where the bank is a shareholder of the firm but does not extend credit to it. We are left with a sample of 7,571 firm-year observations. Moreover, to reduce the 
influence of outliers we also winsorize the top and bottom $1 \%$ of all continuous variables with outliers. Our final sample consists of 992 firms and 7,420 firm-year observations.

\subsection{Banks' dual holding}

We manually collect the information on dual holding by following the steps described below. First, from the Corporate Governance database of CSMAR we assemble detailed information on the 10 largest shareholders and their ownership holding in the firms. We then identify any banks among the top 10. We go through the IPO prospectus of the companies with bank shareholders and ensure that commercial banks were among the original sponsors and shareholders in the IPO of these listed firms. To remain consistent with Lin et al. (2009) and Luo et al. (2011), we exclude bank shareholding obtained from the debt-to-equity swap in SOE reform, because these ownerships held by banks had to be relinquished within the two years following the reform. Moreover, to ensure the validity of our empirical analysis, we apply the term "dual holding" only to firms where banks act as both shareholders and creditors. We apply two proxies for dual holding: the first is the dummy variable Bankdummy, which is equal to 1 if the firm has a bank dual holder and 0 otherwise; the second is Bankshare, which is the percentage of shares held by dual holders. Table 1 summarises dual holdings in China's listed firms over our sample by year. The data reveals that there are 343 firm-year observations with bank dual holders out of the 7,420 firm-year observations. Columns 3 and 4 in Table 1 show that the total number of firms with a bank as a dual holder and the corresponding percentage both decrease over time, from 51 (5.53\%) in 2003 to 38 (4.06\%) in 2010. Columns 5 and 6 show the distribution of firms with bank shareholders (this includes those with bank dual holders and those with banks only as shareholders as well) from 2003 to 2010. The number and percentage of firms having a bank as a shareholder decreases from $84(9.11 \%)$ in 2003 to only 48 (6.13\%) in 2010, which is similar to the figures reported by previous studies using a similar sample (Lin et al., 2009; Luo et al., 2011). However, since firms with a bank as only a shareholder are not related to our theoretical discussion of dual holdings, our focus is on those firms with a bank as a dual holder rather than only as a shareholder.

\begin{tabular}{cccccc}
\multicolumn{6}{c}{ Table 1. Distribution of firms with bank dual holders and firms with banks as shareholders } \\
\hline Year & Total & $\begin{array}{c}\text { Firms with } \\
\text { dual holder }\end{array}$ & $\begin{array}{c}\text { Percentage with } \\
\text { dual holder }\end{array}$ & $\begin{array}{c}\text { Firms with bank } \\
\text { shareholder }\end{array}$ & $\begin{array}{c}\text { Percentage with bank } \\
\text { shareholder }\end{array}$ \\
\hline 2003 & 922 & 51 & $5.53 \%$ & 84 & $9.11 \%$ \\
2004 & 926 & 49 & $5.29 \%$ & 77 & $8.32 \%$ \\
2005 & 928 & 47 & $5.06 \%$ & 74 & $7.97 \%$ \\
2006 & 925 & 40 & $4.32 \%$ & 49 & $5.30 \%$ \\
2007 & 927 & 40 & $4.32 \%$ & 49 & $5.30 \%$ \\
2008 & 928 & 40 & $4.31 \%$ & 49 & $5.28 \%$ \\
2009 & 929 & 38 & $4.09 \%$ & 48 & $5.17 \%$ \\
\hline
\end{tabular}




\begin{tabular}{lccccc}
\hline 2010 & 935 & 38 & $4.06 \%$ & 48 & $5.13 \%$ \\
Total & 7,420 & 343 & $4.62 \%$ & 478 & $6.45 \%$ \\
\hline
\end{tabular}

\subsection{Ownership concentration and owner type}

In order to test our hypothesis that controlling shareholders are able to monitor firm managers and prevent them from colluding with bank managers, we apply two proxies for ownership structure. One is ownership concentration, defined as the ownership held by the largest shareholder for each firm. Another one is ultimate owner type. To ensure that the ultimate owner is able to exert effective monitoring effect, we use $10 \%$ ownership as the cutoff to identify the ultimate owner for each firm of our sample, following La Porta et al. (1999). To do so, we track the ultimate owner by searching the information obtained from the Shareholder Analysis Database from CSMAR. From this database, we are able to collect the names of ultimate owners for each firm, and divide them into four groups: family owner, institutional owner, foreign owner and collective owner.

\subsection{Model specification and variable definition}

To examine whether dual holders can bring more bank loans and determine the different effects of dual holding on access to bank loans for SOEs and non-SOEs, we develop the following equation:

$$
\begin{aligned}
\text { BankLoan }_{i t} & =\alpha_{0}+\alpha_{1} \text { Bank }_{i t-1}+\alpha_{2} \text { Bank }_{i t-1} * \text { NSOE }_{i t-1}+\alpha_{3} \text { NSOE }_{i t-1} \\
& +\alpha_{4} \text { ROS }_{i t-1}+\alpha_{5} Q_{i t-1}+\alpha_{6} \text { Size }_{i t}+\alpha_{7} \text { Tangibility }_{i t} \\
& +\alpha_{8} \text { Political }_{i t}+\alpha_{9} \text { Board }_{i t}+\alpha_{10} \text { Indep }_{i t}+\alpha_{11} \text { Bankloan }_{i t-1} \\
& +\alpha_{12} \text { Relation }_{i t}+\varepsilon_{i t}
\end{aligned}
$$

where $\Delta$ BankLoan is the change in bank loans (i.e. newly granted bank loans) in the current year. We apply two measures as proxies for the change in bank loans: $\Delta$ Totalloan, defined as the change in the ratio of total bank loans to total assets, and $\Delta$ Longloan, defined as the change in the ratio of long-term bank loans to total assets. Bank is the measurement of banks' dual holding. We apply two proxies in the regression respectively: the dummy variable Bankdummy, which is equal to 1 if the firm has a bank dual holder, and the variable Bankshare, which is the percentage of shares held by a bank dual holder. NSOE is a dummy variable, equal to 1 for non-SOEs and 0 for SOEs. ROS is return on sales, which is the proxy for firm performance. $Q$ is the value of Tobin's $Q$ calculated as the ratio of firm market value to replacement value, which is used as a proxy for firm investment opportunity (Firth et al., 2008; Chen et al., 2011). Size is the log of firm total assets. Tangibility is the ratio of tangible assets to firm total assets. Political is a dummy variable equal to 1 if the firm is politically connected. Board is the log of the total number of directors on the boards. Indep is the ratio 
of independent directors to total directors on the boards. Relation is the bank-firm relationship, measured as the number of years since the dual holder first extended credit. We also include year and industry fixed effects. Following previous studies, we use the one-year lag of dual holding, firm performance, and Tobin's Q in the regression.

We also estimate the following model to examine whether dual holders make optimal lending decisions. In the spirit of the argument in the literature that an optimal lending decision is made if a newly granted bank loan is dependent on a firm's profitability (Bertrand et al., 2007; Zheng and Zhu, 2013), we use the sensitivity of newly granted bank loans to a firm's profitability as the proxy for the bank's lending decision, where strongly positive sensitivity indicates an optimal lending decision. The model is expressed as follows:

$$
\begin{aligned}
\Delta \text { BankLoan }_{i t}= & \alpha_{0}+\alpha_{1} \text { Bank }_{i t-1}+\alpha_{2} \text { Bank }_{i t-1} * \operatorname{ROS}_{i t-1}+\alpha_{3} \text { ROS }_{i t-1}+\alpha_{4} Q_{i t-1} \\
& +\alpha_{5} \text { Size }_{i t}+\alpha_{6} \text { Tangibility }_{i t}+\alpha_{7} \text { Political }_{i t}+\alpha_{8} \text { Board }_{i t} \\
& +\alpha_{9} \text { Indep }_{i t}+\alpha_{10} \text { Bankloan }_{i t-1}+\alpha_{11} \text { Relation }_{i t}+\varepsilon_{i t}
\end{aligned}
$$

In contrast to Equation (1), we include one interaction term between dual holding and ROS to test the bank's lending decision. All the other variables are defined as in Equation (1). In both Equations (1) and (2), the dependent variable $\Delta$ BankLoan is the change in the ratio of bank loans to total assets (i.e. newly granted bank loans) in the current year, which is censored at 0 , and thus we apply the Tobit model to estimate our equations (1) and (2).

To examine the investment efficiency, we follow the idea of Bushman et al. (2011) that investment efficiency is measured as the sensitivity of the change in investment expenditure to the change in investment opportunities. This method has also been applied by other studies (Zheng and Zhu, 2013). The model is expressed as follows:

$$
\begin{aligned}
\operatorname{Ln}\left(I_{i t} / I_{i t-1}\right)= & \alpha_{0}+\alpha_{1} \text { Bank }_{i t-1}+\alpha_{2} \text { Bank }_{i t-1} * R E T_{i t-1}+\alpha_{3} \text { RET }_{i t-1} \\
& +\alpha_{4} \text { Leverage }_{i t-1}+\alpha_{5} \text { Income }_{i t}+\alpha_{6} \text { Size }_{i t}+\alpha_{7} \text { Sale }_{i t-1} \\
& +\alpha_{8} \text { Tangibility }_{i t}+\varepsilon_{i t}
\end{aligned}
$$

where $\operatorname{Ln}\left(I_{i t} / I_{i t-1}\right)$ is the log of the change in a firm's investment expenditures in the current year. We follow Firth et al. (2008) to measure investment expenditure as the ratio of net capital expenditure (capital expenditure minus annual depreciation) to total assets in the current year. Prior studies also applied other proxies for investment, which we consider for the robustness tests ${ }^{5}$. RET measures the change in investment opportunities, which equals the log of 1 plus industry stock return. Leverage is defined as the proportion of total debt to total

\footnotetext{
${ }^{5}$ These measures include (1) the ratio of change in net fixed assets plus depreciation to total net fixed assets (Pindado et al., 2011; Firth et al., 2012) and (2) the ratio of cash payments for fixed assets, intangible assets, and other long-term assets less cash receipts from selling these assets to total assets (Chen et al., 2011).
} 
assets. Income is used to measure internal funds available for investments, which is measured as the ratio of net income plus depreciation to total assets. We follow prior studies to control for the rate of sales growth. In particular, Sale is the net sales scaled by total assets. We also include year and industry fixed effects. To remain consistent with the existing literature, we use the one-year lag of leverage in the regression, as well as the sales level. Table 2 summarizes the definitions of all variables used in this study for both univariate and multivariate analysis.

\section{Table 2. Variables and definitions}

\begin{tabular}{ll}
\hline Variable & Definitions \\
\hline Bankdummy & Equals 1 for firm-year observations with bank as a dual holder \\
Bankshare & Percentage of shares held by a bank dual holder \\
Totalloan & Total bank loans/Total assets \\
$\Delta$ Totalloan & The change in Totalloan in current year \\
Longloan & Long-term bank loans/Total assets \\
$\Delta$ Longloan & The change in Longloan in current year \\
Investment (I) & (Capital expenditure-depreciation)/Total assets \\
Ln(I $\left.{ }_{\text {it }} / \mathrm{I}_{\text {it-1 }}\right)$ & Log of the growth of investment expenditure in current year \\
RET & Log of 1 plus industry stock return \\
ROA & Net income/Total assets \\
ROS & Net income/Sales \\
Leverage & Total debt/Total assets \\
Income & Net income + depreciation/Total assets \\
Q & Tobin's Q measured as Market value/Replacement value \\
Size & Log of total assets \\
Sale & Sales/Total assets \\
Tangibility & Tangible assets/Total assets \\
Board & Number of total directors on the boards \\
Indep & Number of independent directors/Total number of directors on board \\
Largest & Ownership of the largest shareholder for each firm \\
Political & Equals 1 for firms with politically connected executives or large shareholders \\
Relation & Log of the number of years since the dual holder first extended credit \\
\hline
\end{tabular}

\section{Empirical results}

\subsection{Summary statistics}

Table 3 presents the summary statistics for dual holding, change in total bank loans, change in long-term bank loans, investment growth, and change in investment opportunity (RET). The average changes in total bank loans and long-term bank loans are $0.07 \%$ and $0.36 \%$, respectively. We also observe that the means of the log of change in investment expenditures and investment opportunities are 0.05 and 8.22, which are similar to those reported by Zheng and Zhu (2013). We also summarize the firm-level total bank loan, longterm bank loan, investment expenditure, and firm characteristics. As Table 3 shows, we find that $4.62 \%$ of total firm-year observations have banks as both shareholders and creditors, and the average ownership of dual holders is $0.10 \%$, with a maximum of $10.17 \%$. We also present the ratios of the average total bank loans and long-term bank loans as $22.88 \%$ and $6.77 \%$, 
respectively, over our sample, which is similar to the 22.3\% reported by Firth et al. (2008). The mean (median) of the ratio of net investment to total assets is $27.01 \%$ (15.02\%), which is close to the $34.1 \%$ (14.8\%) reported by Firth et al. (2008). The sample average Tobin's Q is 1.58 and the median value is 1.23 , and the average internal cash flow ratio is $5.05 \%$, which is similar to the results reported by Pindado et al. (2011) and Chen et al. (2011).

Table 3. Summary statistics

\begin{tabular}{|c|c|c|c|c|c|c|c|}
\hline & Mean & Median & Min & Lower quartile & Higher quartile & Max & Obs \\
\hline Bankdummy (\%) & 4.62 & 0 & 0 & 0 & 0 & 100 & 7420 \\
\hline Bankshare (\%) & 0.10 & 0 & 0 & 0 & 0 & 10.17 & 7420 \\
\hline Totalloan (\%) & 22.88 & 22.5 & 0 & 11.10 & 33.39 & 94.72 & 7420 \\
\hline$\Delta$ Totalloan (\%) & 0.07 & 0 & -48.70 & -3.82 & 4.82 & 68.75 & 7420 \\
\hline Longloan (\%) & 6.77 & 2.58 & 0 & 0 & 9.87 & 66.46 & 7420 \\
\hline$\Delta$ Longloan (\%) & 0.36 & 0 & -33.85 & -1.44 & 1.36 & 53.85 & 7420 \\
\hline Investment (\%) & 27.01 & 15.02 & -28.45 & 6.39 & 28.27 & 266.42 & 7420 \\
\hline $\operatorname{Ln}\left(\mathrm{I}_{\mathrm{it}} / \mathrm{I}_{\mathrm{it}-1}\right)$ & 0.05 & 0.04 & -3.17 & -0.61 & 0.55 & 6.52 & 7420 \\
\hline RET & 8.22 & 5.25 & -81.69 & -10.64 & 48.33 & 75.71 & 7420 \\
\hline ROA (\%) & 2.81 & 2.77 & -48.48 & 0.87 & 5.42 & 46.31 & 7420 \\
\hline ROS (\%) & 5.43 & 4.34 & -29.61 & 1.46 & 9.85 & 69.39 & 7420 \\
\hline Leverage (\%) & 51.09 & 51.97 & 0.02 & 38.55 & 63.95 & 89.36 & 7420 \\
\hline Income (\%) & 5.05 & 5.13 & -8.15 & 2.98 & 8.25 & 11.47 & 7420 \\
\hline Tobin's Q & 1.58 & 1.23 & 0.50 & 1.03 & 1.75 & 14.91 & 7420 \\
\hline Size (million) & 4,530 & 2,260 & 302 & 1,200 & 4,630 & 64,400 & 7420 \\
\hline Sale (\%) & 72.48 & 58.60 & 0.95 & 36.24 & 89.30 & 100.03 & 7420 \\
\hline Tangibility (\%) & 30.03 & 27.22 & 0.20 & 16.05 & 42.51 & 95.91 & 7420 \\
\hline Board & 8.73 & 9 & 1 & 7 & 10 & 20 & 7420 \\
\hline Indep (\%) & 0.41 & 0.36 & 0 & 0.33 & 0.5 & 0.75 & 7420 \\
\hline Largest (\%) & 47.89 & 40.77 & 1.73 & 27.06 & 58.33 & 85.23 & 7420 \\
\hline Political & 0.43 & 0 & 0 & 0 & 1 & 1 & 7420 \\
\hline Relation & 7.06 & 7 & 0 & 3 & 11 & 17 & 7420 \\
\hline
\end{tabular}

This table provides summary statistics of our sample for all variables in the empirical analysis. These variables are defined in Table 2.

\subsection{Empirical results}

\subsubsection{Univariate tests}

To provide some empirical evidence to support our hypotheses, we conduct univariate tests by comparing the mean of our key variables, including the change in total bank loans and change in long-term bank loans, investment growth, and change in investment opportunities, as well as firm performance for firms with and without dual holding (Table 4). Our tests cover the full sample as well as the SOE and non-SOE subsamples. For the full sample we find that dual holding facilitates capital flows and the average changes in total bank-loan ratio and long-term bank-loan ratio are $0.34 \%$ and $0.38 \%$, respectively, for firms with dual holding, which are significantly higher than $-0.08 \%$ and $0.18 \%$, respectively, for firms without dual holding. We further find that firms with a dual holder exhibit significantly higher average growth in investment expenditures (5.20\% versus $-2.18 \%$ ), but lower mean in change in investment opportunities (as measured by RET) than firms without a dual holder 
(7.49 versus 8.27). For both SOE and non-SOE subsamples, the average changes in bankloan ratio, long-term bank-loan ratio and investment growth are significantly higher for firms with dual holding, which is consistent with the evidence from the full sample tests. Some interesting evidence evolves when we turn to other variables. For the SOE subsample we find that the change in investment opportunities (RET) is significantly lower for firms with dual holding than for firms without dual holding. As for the non-SOE subsample, we present that firms with dual holdings have a higher change in investment opportunities (RET) than firms without dual holdings.

Table 4. Univariate tests

\begin{tabular}{|c|c|c|c|c|c|c|c|c|c|}
\hline & \multicolumn{3}{|c|}{ Full sample } & \multicolumn{3}{|c|}{ SOEs } & \multicolumn{3}{|c|}{ Non-SOEs } \\
\hline & With & Without & t-value & With & Without & t-value & With & Without & t-value \\
\hline $\begin{array}{l}\Delta \text { Totalloan } \\
(\%)\end{array}$ & 0.34 & -0.08 & $\begin{array}{l}0.42 * * \\
(2.11)\end{array}$ & 0.29 & 0.02 & $\begin{array}{l}0.27 * * \\
(2.13)\end{array}$ & 0.40 & -0.10 & $\begin{array}{l}0.50 * * \\
(2.41)\end{array}$ \\
\hline $\begin{array}{l}\Delta \text { Longloan } \\
(\%)\end{array}$ & 0.38 & 0.18 & $\begin{array}{l}0.20 * * * \\
(2.68)\end{array}$ & 0.41 & 0.27 & $\begin{array}{l}0.14^{* *} \\
(2.29)\end{array}$ & 0.32 & 0.10 & $\begin{array}{l}0.22 * * * \\
(2.69)\end{array}$ \\
\hline $\operatorname{Ln}\left(\mathrm{I}_{\mathrm{it}} / \mathrm{I}_{\mathrm{it}-1}\right)$ & 5.20 & -2.18 & $\begin{array}{l}7.38^{* * *} \\
(3.18)\end{array}$ & 6.47 & 1.84 & $\begin{array}{l}4.63^{*} \\
(1.87)\end{array}$ & 4.65 & -3.11 & $\begin{array}{l}7.76^{* *} \\
(2.55)\end{array}$ \\
\hline RET & 7.49 & 8.27 & $\begin{array}{l}-0.78^{* *} \\
(-2.46)\end{array}$ & 6.82 & 8.16 & $\begin{array}{l}-1.34 * * * \\
(-2.76)\end{array}$ & 8.83 & 8.36 & $\begin{array}{l}0.47 * \\
(1.93)\end{array}$ \\
\hline ROA (\%) & 2.00 & 2.70 & $\begin{array}{l}-0.70^{*} \\
(-1.93)\end{array}$ & 1.96 & 2.90 & $\begin{array}{l}-0.94 * * \\
(-2.33)\end{array}$ & 2.20 & 1.46 & $\begin{array}{l}0.74 * * \\
(1.96)\end{array}$ \\
\hline ROS (\%) & 4.12 & 5.55 & $\begin{array}{l}-1.43^{* *} \\
(-2.01)\end{array}$ & 3.98 & 5.73 & $\begin{array}{l}-1.75^{* *} \\
(-2.12)\end{array}$ & 5.95 & 5.10 & $\begin{array}{l}0.85^{*} \\
(1.90)\end{array}$ \\
\hline
\end{tabular}

This table summarizes the univariate tests of our key variables between firms with and without dual holding for SOEs and non-SOEs. These variables are defined as in previous tables.

In addition to the differences in the change in bank loans, investment growth and change in investment opportunities, there are also significant differences in accounting-based firm performance (ROA and ROS). In particular, firm performance is significantly lower in firms with dual holding for the full sample and SOE subsample, but is significantly higher in firms with dual holding for the non-SOE subsample. For example, for the full sample the ROA is $2.00 \%$ for firms with dual holding, which is significantly lower than $2.70 \%$ for firms without dual holding (t-value is -1.93). For the SOE subsample, the average ROA is $1.96 \%$ for firms with dual holding, which is significantly lower than $2.90 \%$ (t-value is -2.33 ) for firms without dual holding, while for the non-SOE subsample, this situation is reversed: the average ROA is $2.20 \%$ for firms with dual holding, which is significantly higher than $1.46 \%$ (t-value is 1.96) for firms without dual holding.

\subsubsection{Dual holding and newly granted bank loans}

In this section we conduct a multivariate analysis to examine the effect of dual holding on newly granted bank loans to firms by estimating our equation (1). Across columns 1 and 2, dual holding is significantly and positively related to the change in total bank-loan ratios. For 
example, in column 1 where the dependent variable is the change in total bank-loan ratio, the estimated coefficient on Bankdummy is 0.05, significant at the 5\% level (t-value is 2.45), indicating that dual holding facilitates firms' access to more newly granted bank loans. To test the effect of dual holding in non-SOEs compared to SOEs, we focus on the interaction terms between dual holding and the NSOE dummy. In columns 1 and 2 of Table 5, we find that the estimated coefficients on the interaction terms are all positive and statistically significant, indicating that dual holding gives firms easier access to bank loans, and that this effect is more significant in non-SOEs than SOEs.

Table 5. The effect of dual holding on newly granted bank loans

\begin{tabular}{|c|c|c|c|c|}
\hline \multirow{3}{*}{$\begin{array}{l}\text { Dependent variable } \\
\text { Bankdummy }\end{array}$} & \multicolumn{2}{|c|}{$\Delta$ Totalloan } & \multicolumn{2}{|c|}{$\Delta$ Longloan } \\
\hline & $0.05^{* *}$ & & $0.07^{* * *}$ & \\
\hline & (2.45) & & $(2.90)$ & \\
\hline \multirow[t]{2}{*}{ Bankdummy*NSOE } & $0.01 * *$ & & $0.01 * *$ & \\
\hline & (1.99) & & (2.09) & \\
\hline \multirow[t]{2}{*}{ Bankshare } & & $0.04 * *$ & & $0.03 *$ \\
\hline & & $(2.55)$ & & $(1.92)$ \\
\hline \multirow[t]{2}{*}{ Bankshare*NSOE } & & $0.05 * * *$ & & $0.02 * *$ \\
\hline & & $(2.58)$ & & $(2.07)$ \\
\hline \multirow[t]{2}{*}{ NSOE } & $-0.05 *$ & $-0.05^{* *}$ & -0.01 & -0.01 \\
\hline & $(-1.95)$ & $(-1.96)$ & $(-0.78)$ & $(-0.62)$ \\
\hline \multirow[t]{2}{*}{ ROS } & $0.05 * * *$ & $0.05 * * *$ & $0.04 * * *$ & $0.04 * * *$ \\
\hline & $(5.12)$ & $(5.10)$ & $(2.58)$ & $(2.59)$ \\
\hline \multirow[t]{2}{*}{ Q } & $0.02 *$ & $0.01^{*}$ & $0.02 * *$ & $0.02 * *$ \\
\hline & $(1.71)$ & $(1.75)$ & $(2.13)$ & $(2.15)$ \\
\hline \multirow[t]{2}{*}{ Size } & $0.06 * *$ & $0.06^{* *}$ & $0.02 * * *$ & $0.02 * * *$ \\
\hline & $(5.37)$ & $(5.34)$ & $(3.52)$ & $(3.55)$ \\
\hline \multirow[t]{2}{*}{ Tangibility } & $0.02 * *$ & $0.02 * *$ & $0.01 * * *$ & $0.01^{* *}$ \\
\hline & $(2.03)$ & $(2.01)$ & $(2.28)$ & $(2.27)$ \\
\hline \multirow[t]{2}{*}{ Political } & 0.02 & 0.01 & 0.01 & 0.01 \\
\hline & $(0.10)$ & $(0.14)$ & $(0.33)$ & $(0.31)$ \\
\hline \multirow[t]{2}{*}{ Board } & -0.01 & -0.01 & -0.01 & -0.01 \\
\hline & $(-1.15)$ & $(-1.18)$ & $(-1.21)$ & $(-1.24)$ \\
\hline \multirow[t]{2}{*}{ Indep } & -0.02 & -0.01 & 0.01 & 0.01 \\
\hline & $(-1.23)$ & $(-1.19)$ & $(1.25)$ & $(1.25)$ \\
\hline \multirow[t]{2}{*}{ Bankloan } & $-0.15^{* * * *}$ & $-0.15^{* * * *}$ & $-0.05 * * *$ & $-0.06 * * *$ \\
\hline & $(-5.81)$ & $(-5.79)$ & $(-3.62)$ & $(-3.62)$ \\
\hline \multirow[t]{2}{*}{ Relation } & 0.00 & 0.00 & $0.01^{* *}$ & $0.01 * *$ \\
\hline & $(1.40)$ & (1.39) & $(2.00)$ & (1.99) \\
\hline \multirow[t]{2}{*}{ Constant } & $-0.12^{* * *}$ & $-0.12 * * *$ & $-0.03 * *$ & $-0.03 * *$ \\
\hline & $(-4.90)$ & $(-4.87)$ & $(-2.06)$ & $(-2.05)$ \\
\hline Year fixed effects & Included & Included & Included & Included \\
\hline Industry fixed effects & Included & Included & Included & Included \\
\hline Adjusted $\mathrm{R}^{2}$ & 0.34 & 0.35 & 0.13 & 0.15 \\
\hline Observations & 7420 & 7420 & 7420 & 7420 \\
\hline
\end{tabular}

The dependent variables are the change in the ratio of total bank loans to total assets and the change in the ratio of long-term bank loans to total assets. Bankdummy is a dummy variable equal to 1 if the firm has a bank dual holder and 0 otherwise. Bankshare is the percentage of shares held by a bank dual holder. NSOE is a dummy variable equal to 1 for non-SOEs and 0 for SOEs. ROS is the return on sales. Q is the ratio of firm market value to replacement value. Size is the log of firm's total assets. Tangibility is the ratio of firm's tangible assets to total assets. Political is a dummy variable equal to 1 if the firm is politically connected. Board is the log of the number of total directors on the board. Indep is the ratio of independent directors to total directors on the board. Bankloan is the bank-loan ratio of the previous year. Relation is the log of years since the firm was first granted loans from the dual holder. 
The T-statistics are in parentheses, and were computed using the White (1980) heteroscedasticity robust standard error, clustered by firm; *,**, and $* * *$ indicate the significance levels at $10 \%, 5 \%$, and $1 \%$, respectively.

In columns 3 and 4, we use the change in the ratio of long-term bank loans to total assets as the dependent variable to examine whether dual holding leads to more newly granted longterm bank loans. The results in columns 3 and 4 show that dual holding is positively related to the change in long-term bank loans, although it is marginally significant for the model of Bankshare (significant at the 10\% level). This suggests that having a dual holder can reduce the conflicts of interest and information asymmetry between banks and firms, which results in lower monitoring costs and a greater propensity towards long-term bank loans. We also check the significance of coefficients on interaction terms to conclude that dual holding is more significant for banks granting new long-term loans to non-SOEs. All of these results help to support our hypothesis $\mathrm{H} 1$ that dual holding can alleviate conflicts of interest and information asymmetry between shareholders and creditors, which may lead to easier access to more (long-term) bank loans, especially for non-SOEs.

\subsubsection{Dual holding and banks' lending decisions}

In this section we conduct a multivariate analysis to examine the effect of dual holding on banks' lending decisions by estimating our Equation (2) for the full sample, and for the SOE and non-SOE subsamples (Table 6). The presence of a dual holder or higher equity holding by creditors is positively and significantly associated with newly granted bank loans for non-SOEs, while it only matters marginally for SOEs. In the spirit of previous studies (Zheng and Zhu, 2013), we apply the sensitivity of newly granted bank loans to firm profitability as an indication of whether banks make optimal lending decisions, and a strong sensitivity between the newly granted bank loan and firm profitability suggests an optimal lending decision. We observe that firm profitability measured by ROS has a strong positive and significant relation with newly granted bank loans across all specifications, which indicates that firm profitability effectively determines the amount of newly granted bank loans. This result is consistent with those obtained by previous studies that banks tend to allocate loans to profitable firms using their commercial judgments (Cull and $\mathrm{Xu}$, 2005; Firth et al., 2009; Zheng and Zhu, 2013).

Table 6. Effect of dual holding on bank lending decisions

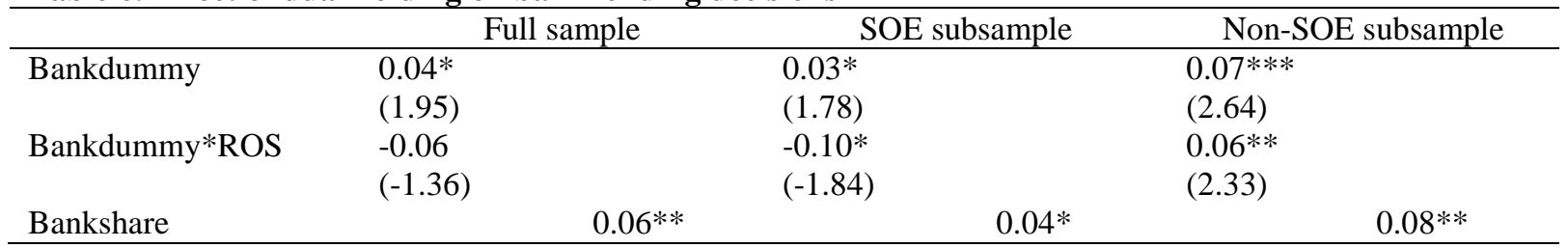




\begin{tabular}{|c|c|c|c|c|c|c|}
\hline & & $(2.40)$ & & $(1.64)$ & & $(2.27)$ \\
\hline \multirow[t]{2}{*}{ Bankshare*ROS } & & -0.02 & & $-0.02 * *$ & & $0.02 * * *$ \\
\hline & & $(-1.01)$ & & $(-2.25)$ & & $(2.87)$ \\
\hline \multirow[t]{2}{*}{ ROS } & $0.05 * * *$ & $0.05^{* * *}$ & $0.05 * * *$ & $0.05 * * *$ & $0.04^{* *}$ & $0.04^{* *}$ \\
\hline & $(4.56)$ & $(4.51)$ & $(4.13)$ & (3.91) & $(2.23)$ & $(2.38)$ \\
\hline \multirow[t]{2}{*}{ Q } & $0.02 *$ & $0.02 *$ & $0.03^{*}$ & $0.02 *$ & $0.02 * *$ & $0.01^{* *}$ \\
\hline & (1.90) & (1.88) & (1.87) & (1.79) & $(2.40)$ & (2.39) \\
\hline \multirow[t]{2}{*}{ Size } & $0.03 * * *$ & $0.03^{* * *}$ & $0.03^{* * *}$ & $0.03 * * *$ & 0.02 & 0.02 \\
\hline & (3.09) & (3.14) & $(2.67)$ & $(2.72)$ & $(0.53)$ & $(0.57)$ \\
\hline \multirow[t]{2}{*}{ Tangibility } & $0.02 * *$ & $0.08 * *$ & $0.02 *$ & $0.02 *$ & 0.02 & 0.02 \\
\hline & $(2.42)$ & $(2.38)$ & $(1.78)$ & (1.78) & (1.53) & $(1.47)$ \\
\hline \multirow[t]{2}{*}{ Political } & 0.01 & 0.01 & 0.01 & 0.01 & 0.02 & 0.01 \\
\hline & $(0.27)$ & $(0.34)$ & $(0.05)$ & $(0.04)$ & $(0.26)$ & $(0.30)$ \\
\hline \multirow[t]{2}{*}{ Board } & -0.01 & -0.01 & -0.01 & -0.01 & -0.02 & -0.02 \\
\hline & $(-1.23)$ & $(-1.22)$ & $(-0.55)$ & $(-0.60)$ & $(-1.60)$ & $(-1.62)$ \\
\hline \multirow[t]{2}{*}{ Indep } & -0.01 & -0.02 & -0.02 & -0.02 & -0.04 & -0.02 \\
\hline & $(-1.31)$ & $(-1.26)$ & $(-0.67)$ & $(-0.65)$ & $(-1.53)$ & $(-1.49)$ \\
\hline \multirow[t]{2}{*}{ Bankloan } & $-0.15^{* * *}$ & $-0.15^{* * *}$ & $-0.15^{* * *}$ & $-0.15 * * *$ & $-0.12 * * *$ & $-0.12 * * *$ \\
\hline & $(-5.50)$ & $(-5.55)$ & $(-4.59)$ & $(-4.66)$ & $(-3.20)$ & $(-3.21)$ \\
\hline \multirow[t]{2}{*}{ Relation } & $0.01 *$ & $0.01 *$ & 0.01 & 0.01 & $0.01 *$ & $0.01 * *$ \\
\hline & $(1.90)$ & $(1.84)$ & $(1.00)$ & $(0.96)$ & (1.91) & $(1.96)$ \\
\hline \multirow[t]{2}{*}{ Constant } & $-0.06 * *$ & $-0.06^{* *}$ & $-0.07 * *$ & $-0.07 * *$ & 0.01 & 0.09 \\
\hline & $(-2.39)$ & $(-2.46)$ & $(-2.35)$ & $(-2.41)$ & $(0.18)$ & $(0.16)$ \\
\hline Year fixed effects & Included & Included & Included & Included & Included & Included \\
\hline Industry fixed effects & Included & Included & Included & Included & Included & Included \\
\hline Adjusted $\mathrm{R}^{2}$ & 0.30 & 0.30 & 0.35 & 0.35 & 0.24 & 0.25 \\
\hline Observations & 7420 & 7420 & 5077 & 5077 & 2343 & 2343 \\
\hline
\end{tabular}

The dependent variable is the change in the ratio of total bank loans to total assets. Bankdummy is a dummy variable equal to 1 if the firm has a bank dual holder and 0 otherwise. Bankshare is the percentage of shares held by a bank dual holder. ROS is the return on sales. Q is the ratio of firm market value to replacement value. Size is the log of firm total assets. Tangibility is the ratio of firm's tangible assets to total assets. Political is a dummy variable equal to 1 if the firm is politically connected. Board is the log of number of total directors on the board. Indep is the ratio of independent directors to total directors on the board. Bankloan is the bank-loan ratio of the previous year. Relation is the log of years since the firm was first granted loans from the dual holder.

The T-statistics are in parentheses, and were computed using the White (1980) heteroscedasticity robust standard error, clustered by firm; *, **, and *** indicate the significance levels at $10 \%, 5 \%$, and $1 \%$, respectively.

When we turn to interaction terms between dual holding and ROS, more evidence emerges. These interaction terms allow us to examine how the presence of dual holding affects bank lending decisions for both SOEs and non-SOEs. For the full sample, the estimated coefficients on both Bankdummy*ROS and Bankshare*ROS are negative, suggesting that dual holding may distort banks' lending decisions. However, when the full sample is divided into SOE and non-SOE subsamples, we find that the attenuating effect of dual holding on banks' lending decisions only exists for SOEs, while the estimated coefficients on interaction terms for non-SOEs turn out to be positive and statistically significant. This suggests that unlike for SOEs, dual holding can help financially healthier non-SOEs to get more bank loans, which indicates optimal lending decisions for non-SOEs. These results lend support to our hypothesis H2a that dual holding results in more effective monitoring for non-SOEs than SOEs. For example, in column 6 for non-SOEs, the estimated 
coefficients on Bankdummy*ROS and ROS are 0.06 and 0.04, respectively, both statistically significant at the 5\% level, suggesting that dual holding results in optimal lending decisions to non-SOEs. Overall, our findings from Table 6 suggest that banks exercise less monitoring and less-optimal lending decisions for SOEs, while dual holding is effective in banks' monitoring and their lending decisions for non-SOEs. Among the control variables, we find that political connection facilitates a firm's access to new bank loans, though the estimated coefficients are insignificant. We also observe that a long-term bank-firm relationship (measured by the log of number of years since the dual holder first extended loans to firms) helps non-SOEs obtain more new bank loans, while this effect is insignificant for SOEs. Replacing ROS with ROA (return on assets) in the regression gives similar results.

\subsubsection{Dual holding and firm investment efficiency}

In the following section we estimate Equation (3) to conduct a multivariate analysis to examine the effect of dual holding on investment efficiency.

Table 7 shows the results of the regression of the effect of dual holding on firms' investment efficiency, measured as the sensitivity of the investment growth to the change in investment opportunities for the full sample, as well as the SOE and non-SOE subsamples. The estimated coefficients on RET are significantly positive for the full sample as well as both subsamples, indicating that investment is efficient: firm investment growth positively responds to the change in investment opportunity. We are more concerned about the interaction terms between dual holding and the change in investment opportunities (RET) in each regression, and we observe some interesting evidence. For the full sample we observe negative coefficients on Bankdummy*RET and Bankshare*RET in both specifications, but they are insignificant. For the SOE subsample, the effect of dual holding on investment efficiency becomes negative and statistically significant. For non-SOEs, the effect of dual holding is positive, indicating that dual holding can enhance investment efficiency for nonSOEs. For example, in columns 3 and 5, the estimated coefficients on Bankdummy*RET are 0.02 and 0.02 , both significant at the $5 \%$ level (t-values are -2.17 and 2.20 , respectively). Overall, our results support our hypothesis H2b that dual holding distorts firms' investment decisions for SOEs, while it improves them for non-SOEs.

Table 7. Impact of dual holding on investment efficiency

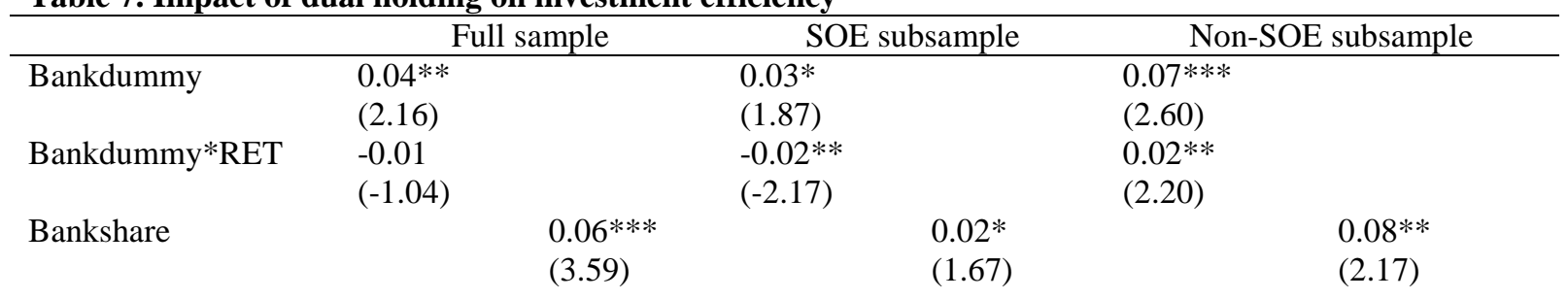




\begin{tabular}{lllllll} 
Bankshare*RET & & -0.01 & & $-0.02^{* * *}$ & & $0.03^{* *}$ \\
RET & $0.05^{* *}$ & $(-0.66)$ & & $(-2.75)$ & & $(2.21)$ \\
& $(2.38)$ & $(2.51)$ & $(2.25)$ & $(2.46)$ & $(1.78)$ & $0.05^{* *}$ \\
Leverage & $-0.33^{* * *}$ & $-0.33^{* * *}$ & $-0.32^{* * *}$ & $-0.32^{* * *}$ & -0.20 & -0.19 \\
& $(-3.67)$ & $(-3.69)$ & $(-3.09)$ & $(-3.12)$ & $(-1.09)$ & $(-0.98)$ \\
Income & $0.98^{* * *}$ & $0.98^{* * *}$ & $1.72^{* * *}$ & $1.72^{* * *}$ & 0.41 & 0.40 \\
& $(3.91)$ & $(3.90)$ & $(6.29)$ & $(6.29)$ & $(1.51)$ & $(1.46)$ \\
Size & $0.04^{* * *}$ & $0.04^{* * *}$ & $0.03^{* *}$ & $0.03^{* *}$ & 0.05 & 0.05 \\
& $(3.63)$ & $(3.64)$ & $(2.57)$ & $(2.55)$ & $(1.48)$ & $(1.55)$ \\
Sale & 0.01 & 0.01 & -0.03 & -0.03 & 0.02 & 0.01 \\
& $(0.01)$ & $(0.04)$ & $(-0.23)$ & $(-0.20)$ & $(0.02)$ & $(0.02)$ \\
Tangibility & $0.79 * * *$ & $0.80^{* * *}$ & $0.74 * * *$ & $0.75 * * *$ & $0.97 * * *$ & $0.91^{* * *}$ \\
& $(7.34)$ & $(7.72)$ & $(9.18)$ & $(9.20)$ & $(6.42)$ & $(6.35)$ \\
Constant & $-0.67 * * *$ & $-0.67 * * *$ & $-0.50^{* *}$ & $-0.50^{*}$ & -0.72 & -0.77 \\
& $(-2.80)$ & $(-2.80)$ & $(-1.97)$ & $(-1.95)$ & $(-1.12)$ & $(-1.19)$ \\
Year fixed effects & Included & Included & Included & Included & Included & Included \\
Industry fixed effects & Included & Included & Included & Included & Included & Included \\
Adjusted R ${ }^{2}$ & 0.33 & 0.27 & 0.37 & 0.28 & 0.32 & 0.27 \\
Observations & 7420 & 7420 & 5077 & 5077 & 2343 & 2343 \\
\hline
\end{tabular}

The dependent variable is the change in investment expenditure. Investment expenditure is defined as the ratio of net capital expenditure to total assets. Bankdummy is a dummy variable equal to 1 if the firm has a bank dual holder and 0 otherwise. Bankshare is the percentage of shares held by a bank dual holder. RET is measured as the log of 1 plus industry stock return. Leverage is the ratio of bank loans to total assets. Income is the ratio of internal cash flow to total assets. Size is the log of firm total assets. Sale is the ratio of sales to total assets. Tangibility is the ratio of firm's tangible assets to total assets.

The T-statistics are in parentheses, and were computed using the White (1980) heteroscedasticity robust standard error, clustered by firm; *, **, and *** indicate the significance levels at $10 \%, 5 \%$, and $1 \%$, respectively.

In addition, in all the regressions we find that the coefficients on Leverage are negative and statistically significant at the $1 \%$ level for the full sample and the SOE subsample estimation. For example, in column 1 the coefficient on Leverage is -0.33 and the t-value is -3.67. These results are consistent with previous studies that a firm's leverage is negatively related to firm investment expenditures (Lang et al., 1996; Firth et al., 2008; Chen et al., 2011). Among other control variables, we also find that the estimated coefficients on Income are positive and statistically significant in all specifications (except for the non-SOE subsample), which is consistent with Pindado et al. (2011), who suggest that funds available to firms are positively related to firms' investment decisions. We further find that tangible assets are positively and significantly related to investment growth, which echoes the findings by Aviazian et al. (2005) and Firth et al. (2008). However, we do not find a significant relationship between firm sales level and investment growth. Overall, the results of our equation are consistent with previous evidence.

\subsubsection{Dual holding and ownership structure in non-SOEs}

In the following section, we conduct a multivariate analysis to examine how ownership structure (ownership concentration and owner type) affects the relationship between dual holding and non-SOEs' lending decisions and investment efficiencies; the aim is to provide 
direct evidence of the role of large shareholders in monitoring firm managers by averting their collusion with bank managers. First, we consider the effect of ownership concentration. We create a dummy variable, Concentration, which is equal to 1 if the ownership concentration is higher than the median value and 0 if it is lower. We include the additional interaction terms Bankdummy*ROS*Concentration and Bankdummy*RET*Concentration in both lending-decision and investment-efficiency regressions. Moreover, we notice that ownership concentration may be endogenously determined, and thus choose two-stage least square to address this issue. In the first stage, we follow Wei et al. (2005) that ownership is more likely to be concentrated if the firm is operating in a strategic or important industry, and choose the strategic or important industry indicator (SID) as the instrumental variable, and then regress ownership concentration against it as well as against control variables. In the second stage, we use the predicted value of ownership concentration obtained from the first stage. Panel A of Table 8 gives the results of both stages.

In addition, we also identify who is the controlling shareholder and examine which type of controlling shareholder is more effective in monitoring firm managers and preventing them from colluding with bank managers. Among the non-SOEs with more highly concentrated ownership, we track the ultimate owner for each firm and identify four types of owner: family, institutional, foreign, and collective. Again, we run Equations (2) and (3) for each subsample (Panels B and C in Table 8).

Table 8. Lending decision and investment efficiency for the non-SOE subsample

Panel A: Effect of ownership concentration on the relationship of banks' dual holding with lending decision and investment efficiency

\begin{tabular}{|c|c|c|c|c|}
\hline & \multirow{2}{*}{\multicolumn{2}{|c|}{\begin{tabular}{l}
\multicolumn{1}{c}{ First stage } \\
Dependent variable is \\
ownership concentration
\end{tabular}}} & \multicolumn{2}{|c|}{ Second stage } \\
\hline & & & $\begin{array}{l}\text { Lending-decision } \\
\text { regression }\end{array}$ & $\begin{array}{l}\text { Investment- } \\
\text { efficiency regression }\end{array}$ \\
\hline SID & $0.16^{* * *}(2.62)$ & & & \\
\hline Bankdummy & & & $0.07 * *(2.02)$ & $0.06 * * *(2.77)$ \\
\hline Bankdummy*ROS & & & $0.03 *(1.82)$ & \\
\hline Bankdummy*ROS*Concentration & & & $0.16 *(1.71)$ & \\
\hline Bankdummy*RET & & & & $0.02(0.76)$ \\
\hline Bankdummy*RET*Concentration & & & & $0.04 *(1.86)$ \\
\hline $\begin{array}{l}\text { Other variables included in the reg } \\
\text { such as return on sales, firm size, } \\
\text { lagged loan level, bank-firm relati } \\
\text { year and industry fixed effects. }\end{array}$ & $\begin{array}{l}\text { ession are those } \\
\text { angible assets, b } \\
\text { nship, change it }\end{array}$ & $\begin{array}{l}\text { om the } b \\
\text { ard size } \\
\text { investm }\end{array}$ & $\begin{array}{l}\mathrm{k} \text { lending and inve } \\
\text { Idependent director } \\
\text { opportunity, lever }\end{array}$ & $\begin{array}{l}\text { efficiency equations, } \\
\text {, political connection, } \\
\text { et income, sales, and }\end{array}$ \\
\hline Adjusted $\mathrm{R}^{2}$ & 0.45 & & 0.28 & 0.33 \\
\hline Observations & 2343 & & 2343 & 2343 \\
\hline Panel B: Effect of owner types on $t$ & e relationship be & veen ban & dual holding and l & g decision \\
\hline & Family owner & $\begin{array}{l}\text { Institut } \\
\text { owner }\end{array}$ & al $\quad$ Foreign & Collective owner \\
\hline Bankdummy & $0.06 * *$ & 0.02 & 0.02 & 0.02 \\
\hline & $(2.15)$ & (1.59) & $(0.11)$ & $(1.20)$ \\
\hline Bankdummy*ROS & $0.37 * *$ & 0.03 & $0.23 * * *$ & 0.00 \\
\hline & $(2.02)$ & $(0.23)$ & $(3.21)$ & $(-0.01)$ \\
\hline
\end{tabular}

Other variables included in the regression are return on sales, firm size, tangible assets, board size, independent 
director ratio, political connection, lagged loan level, bank-firm relationship, and year and industry fixed effects.

$\begin{array}{lllll}\text { Adjusted } \mathrm{R}^{2} & 0.13 & 0.20 & 0.25 & 0.07 \\ \text { Observations } & 1177 & 561 & 358 & 203\end{array}$

Panel C: Effect of owner types on the relationship between banks' dual holding and investment efficiency

\begin{tabular}{lllll}
\hline Bankdummy & $0.09^{*}$ & 0.02 & 0.03 & 0.07 \\
Bankdummy*RET & $(1.79)$ & $(1.24)$ & $(1.01)$ & $(0.78)$ \\
& $0.06^{*}$ & 0.08 & $0.05^{* * *}$ & -0.45 \\
& $(1.67)$ & $(1.36)$ & $(5.29)$ & $(-0.73)$
\end{tabular}

Other variables included in the regression are change in investment opportunities, firm size, tangible assets, leverage, board size, independent director ratio, net income, sales, and year and industry fixed effects.

$\begin{array}{lllll}\text { Adjusted } \mathrm{R}^{2} & 0.39 & 0.33 & 0.69 & 0.30\end{array}$

$\begin{array}{lllll}\text { Observations } & 1177 & 561 & 358 & 203\end{array}$

This table reports the additional test results for the non-SOE subsample. Panel A reports the ownership concentration effect on the relationship of banks' dual holding with lending decision and investment efficiency using two-stage least square methods. Panels B and C report the results for those with different controlling shareholders.

As shown in Panel A in Table 8, our previous conclusion that dual holding can improve lending decisions and enhance investment efficiency still holds, as reflected by the significantly positive coefficients on Bankdummy*ROS and Bankdummy*RET in the second stage. More importantly, we observe that the effect of banks' dual holding is more significant for non-SOEs with higher concentrated ownership. These results suggest that in non-SOEs, higher ownership concentration can exert effective monitoring on potential collusion between firm managers and bank managers; this monitoring will lead to optimal lending decisions and more efficient investment. Within the subsample of non-SOEs with higher concentrated ownership, we further run regressions for groups of firms with each type of controlling shareholder that we have identified, and we observe that our previous conclusions hold for firms where families or foreign investors are the ultimate owners. In other words, controlling families and foreign investors are more able to exert monitoring effects than institutional shareholders and collective shareholders as controlling shareholders, which supports our hypothesis H3.

\subsection{Additional analysis: Bank loan contract evidence}

In the above analysis, we focus on the change in the aggregate bank loans (Bankloan) each year at the firm level. Bankloan measures the total amount of loans borrowed from all financial institutions including the dual holders. One potential drawback of this firm-level approach is that it does not show the exact amount of loans borrowed from the dual holders. Lacking information may lead to identification problems because the dual holders may not necessarily have sufficient incentives to monitor the loans lent by other financial institutions. In this section, to provide direct evidence of the effect of dual holding on bank loan granting, we focus specifically on newly granted bank loans to each firm from a dual holder by conducting multivariate analysis at the bank loan level. The purpose of this analysis is to 
explicitly identify the bank loan awarded by the dual holder, and examine whether dual holding facilitates more credit from dual holders and determine its effects on bank lending decisions.

To do so, we apply the bank loan dataset from the CSMAR to provide additional evidence regarding a bank's lending decision and try to relate dual holding to the specific newly granted bank loans by the dual holder. From the bank loan dataset of the CSMAR database, we collect 2,040 new bank loan announcements within our sample from 2003 to 2010. We are also able to obtain detailed information on lending terms for each loan, including loan amount, interest rate, loan maturity, lending bank, whether the loan is guaranteed by a third party, and so on. We delete 54 observations with missing information on the loan amounts, and finally have 1,986 observations. Thus, for the multivariate analysis, we conduct a bank loan level regression by regressing the ratio of newly granted bank loans to firm assets of the previous year against dual holding and a set of control variables. Moreover, we replace Bankdummy with a new dummy variable, Newdummy, equal to 1 if the firm with dual holding obtains new bank loans from the dual holder and 0 otherwise. Consistent with our Newdummy variable, we also have Newshare, defined as the shareholding of the dual holder where the Newdummy is equal to 1 . The results are reported in Table 9 . The estimated coefficients on our key variables are broadly similar to those reported in Table 6 . The empirical results suggest that dual holders would like to extend more credit to firms where they hold equity ownership on average, represented by the significantly positive coefficients on Newdummy and Newshare across six specifications (except for the specification in column 3). The interaction terms also show consistent sign and significance with those in Table 6 (except for the specification in column 3). For example, in columns 5 and 6 for non-SOEs, the positive coefficients on interaction terms suggest that a new bank loan granted from a dual holder is dependent on a firm's profitability for non-SOEs, while the negative coefficients suggest that the lending decision is distorted for SOEs with dual holding. Overall, compared with the results from Table 6, our main findings are still valid using bank loan level data.

Table 9. Dual holding and newly granted bank loan

\begin{tabular}{|c|c|c|c|c|c|c|}
\hline 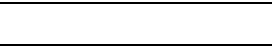 & \multicolumn{2}{|c|}{ Full sample } & \multicolumn{2}{|c|}{ SOE subsample } & \multicolumn{2}{|c|}{ Non-SOE subsample } \\
\hline Newdummy & $\begin{array}{l}0.29 * * \\
(2.10)\end{array}$ & & $\begin{array}{l}0.03 \\
(1.45)\end{array}$ & & $\begin{array}{l}0.41^{* *} \\
(2.30)\end{array}$ & \\
\hline Newdummy*ROS & $\begin{array}{l}-0.23 \\
(-1.14)\end{array}$ & & $\begin{array}{l}-0.43 \\
(-1.31)\end{array}$ & & $\begin{array}{l}0.03 * * \\
(2.04)\end{array}$ & \\
\hline Newshare & & $\begin{array}{l}0.01^{* *} \\
(2.36)\end{array}$ & & $\begin{array}{l}0.01 * * \\
(2.02)\end{array}$ & & $\begin{array}{l}0.46 * * \\
(2.50)\end{array}$ \\
\hline Newshare*ROS & & $\begin{array}{l}-0.01 \\
(-0.94)\end{array}$ & & $\begin{array}{l}-0.09 * * \\
(-2.55)\end{array}$ & & $\begin{array}{l}0.06^{* * *} \\
(2.81)\end{array}$ \\
\hline
\end{tabular}




\begin{tabular}{lllllll}
\hline ROS & $0.08^{* *}$ & $0.10^{* *}$ & $0.02^{* *}$ & $0.06^{* *}$ & $0.10^{* *}$ & $0.14^{* *}$ \\
& $(2.33)$ & $(1.97)$ & $(2.29)$ & $(2.30)$ & $(2.48)$ & $(2.35)$
\end{tabular}

Control variables include firm size, tangible assets, board size, independent director ratio, political connection, and year and industry fixed effects.

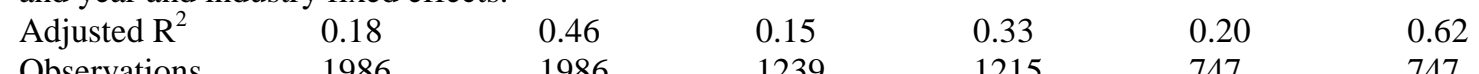

$\begin{array}{lllllll}\text { Observations } & 1986 & 1986 & 1239 & 1215 & 747 & 747\end{array}$

This table reports the results of using single bank loan data, and the regression above is conducted at the bankloan level.

The T-statistics are in parentheses, and were computed using the White (1980) heteroscedasticity robust standard error, clustered by firm; *, **, and *** indicate the significance levels at $10 \%, 5 \%$, and $1 \%$, respectively.

\subsection{Robustness tests for the endogeneity issue}

As we explained before, commercial banks were initially encouraged to participate in the sponsorship and underwriting business of the IPO of large SOEs, but since 1995, according to the Commercial Bank Law (revised in 2003), have been prohibited from holding new ownership in non-financial companies. This indicates that banks' shareholding could not be increased, but that dual holders can still relinquish their original equity position due to observable and non-observable factors, so in this sense dual holding still suffers from an endogeneity issue. Therefore, in the following sections, we try to address this endogeneity issue by applying the event-study method, natural experiment, two-stage least square and fixed-effect regression.

\subsubsection{Event-study method: Market reaction to the announcements of new bank loans and mergers and acquisitions}

The basic assumption of using the event-study method is that the event is purely exogenous, and thus the method avoids endogeneity concerns (Bhagat and Romano, 2007; Fan et al., 2008). In the spirit of Zheng and Zhu (2013), we choose the announcements of bank loans and mergers and acquisitions as exogenous events and examine lending decisions and investment efficiencies by focusing on how investors evaluate these announcements. Specifically, the announcement effect is measured by the market-adjusted cumulative abnormal returns (CAR) around the announcements using the market-adjusted excess return model. We choose three days in the event window $(-1,+1)$, and 230 days as the estimation window $(-240,-10)$. Our CAR calculation is consistent with the method applied by Huang et al. (2012).

In the previous section, we examined the effect of dual holding on banks' lending decisions from the firm's perspective. In this section, we examine the effect of dual holding on lending decisions from the perspective of outside investors. In particular, we examine 
whether dual holding affects bank lending decisions reflected in the market reaction to bank loan announcements.

Following the same sample of bank loans used in Table 9, we calculate the three-day CAR around each bank loan announcement and obtain 1,997 three-day CARs observations. Empirically, we estimate the regression by replacing the dependent variables in Table 9 with the three-day CAR around bank loan announcements (Table 10). The estimated coefficients of our key variables are reported in the table. The empirical results suggest that in the investors' opinion, the bank loans granted to SOEs with dual holding are of low efficiency, while banks make efficient lending decisions to non-SOEs with dual holding.

Table 10. The effect of dual holding on market reactions to bank loan announcements

\begin{tabular}{llccc}
\hline \multicolumn{5}{l}{ Dependent variable: Three-day CARs around bank loan announcements } \\
\hline \multicolumn{2}{r}{ Full sample } & \multicolumn{2}{c}{ SOE subsample } & Non-SOE subsample \\
\hline Bankdummy & -0.02 & -0.09 & $0.06^{* *}$ \\
Bankshare & $(-1.17)$ & $(-1.48)$ & $-0.02^{*}$ & $(2.45)$ \\
& & -0.01 & $(-1.85)$ & $0.02^{* *}$
\end{tabular}

Control variables include return on sales, firm size, tangible assets, board size, independent director ratio, political connection, lagged loan level, bank-firm relationship, and year and industry fixed effects.

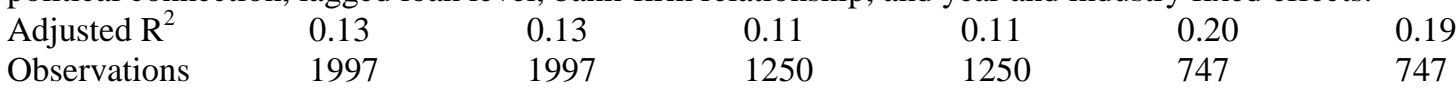

This table reports the market reaction to bank loan announcements. The dependent variable is the three-day CAR around bank loan announcements.

The T-statistics are in parentheses, and were computed using the White (1980) heteroscedasticity robust standard error, clustered by firm; *, **, and $* * *$ indicate the significance levels at $10 \%, 5 \%$, and $1 \%$, respectively.

We also examine the effect of a bank's dual holding on investment efficiency from the investors' perspective. In particular, we examine the market reaction to announcements of mergers and acquisitions. The purpose is to see whether the market reacts to M\&A announcements in such a way that banks' dual holding distorts lending decisions and reduces investment efficiency for SOEs, while improving lending decisions and enhancing investment efficiency for non-SOEs.

We obtain the sample of M\&A announcements and individual daily stock returns from the Mergers and Acquisitions and Individual Stock Trading database from the CSMAR dataset. We obtain 17,847 M\&A events between 2003 and 2010. We apply the three-day market-adjusted CAR around M\&A announcements as the dependent variable; Table 11 presents the regression results of dual holding on market reaction to M\&A announcements. The estimated coefficients on our key variables, namely the measurements of dual holding, are negative for the full sample and SOE subsample, and only significant for Bankshare in the SOE subsample; in contrast, they become positive and significant for the non-SOE subsample. The empirical results suggest that investors would regard dual holding-related 
investment expenditure as less efficient or inefficient on average. This view from the investor's perspective becomes more significant for SOEs. However, investors view the dual holding-related investment expenditure as more efficient for non-SOEs, as it is connected to the increase in investment opportunities more closely than it is for SOEs. Generally, this evidence supports our argument that dual holding in SOEs leads to less efficient investment, while it enhances the investment efficiency for non-SOEs.

Table 11. The effect of dual holding on market reaction to M\&A announcements Dependent variable: Three day CAR around M\&A announcements

\begin{tabular}{|c|c|c|c|c|c|c|}
\hline \multirow{2}{*}{ Bankdummy } & \multicolumn{2}{|c|}{ Full sample } & \multicolumn{2}{|c|}{ SOE subsample } & \multicolumn{2}{|c|}{ Non-SOE subsample } \\
\hline & $\begin{array}{l}-0.09 \\
(-0.72)\end{array}$ & & $\begin{array}{l}-0.16 \\
(-1.09)\end{array}$ & & $\begin{array}{l}0.15^{* *} \\
(2.09)\end{array}$ & \\
\hline Bankshare & & $\begin{array}{l}-0.10 \\
(-0.30)\end{array}$ & & $\begin{array}{l}-0.28 * * \\
(-2.07)\end{array}$ & & $\begin{array}{l}0.17 * * \\
(2.26)\end{array}$ \\
\hline
\end{tabular}

Control variables include RET, leverage, income, firm size, sales, tangible assets, largest shareholder ownership, and year and industry fixed effects.

\begin{tabular}{|c|c|c|c|c|c|}
\hline Adjusted $\mathrm{R}^{2}$ & 0.07 & 0.07 & 0.09 & 0.09 & 0.07 \\
\hline Observations & 17847 & 17847 & 11780 & 11780 & 6067 \\
\hline
\end{tabular}

This table reports the results of the effect of dual holding on the market reaction to the announcements of M\&A. The dependent variable is the three-day CAR around M\&A announcements.

The T-statistics are in parentheses, and were computed using the White (1980) heteroscedasticity robust standard error, clustered by firm; *,**, and *** indicate the significance levels at $10 \%, 5 \%$, and $1 \%$, respectively.

\subsubsection{Natural experiment of a stimulus package}

In this section, we apply an economic stimulus package as a natural experiment to test whether our results are robust to the corrections for the endogeneity issue. We argue that an economic stimulus package is an exogenous shock on bank loan supply, at least with respect to any individual firm, that significantly increases the funds available for firms' investment expenditures. Holding dual holdings constant, this shock to the funds available increases the expected level of lending and investment expenditures. To provide empirical evidence, we repeat our above analysis by adding one dummy variable, Stimulus, which is equal to 1 for firm-year observations during the economic stimulus package period between 2009 and 2010 and 0 during the pre-economic stimulus package period.

We report the results in Table 12 below (only key variables are reported). In Panel A we report the banks' lending decision regression where the dependent variable is the change in the ratio of bank loan to total assets. We observe that estimated coefficients on dual holding are positive in all specifications, and statistically significant for the non-SOEs subsample, while insignificant for the SOEs subsample. We are more concerned about the interaction term between dual holding, ROS and the stimulus package dummy, Bankdummy*ROS*Stimulus and Bankshare*ROS*Stimulus. We find a negative and statistically significant coefficient for this interaction term for SOEs, but a positive 
coefficient for non-SOEs (only significant for the Bankshare model), which indicates that an economic stimulus package further distorts banks' lending decisions to SOEs, while it improves lending decisions to non-SOEs.

In Panel B we report the firm investment efficiency regression, where the dependent variable is investment growth. We find estimated coefficients on dual holding consistent with those reported in previous tables. Again, we are more concerned about the interaction term between dual holding, the change in investment opportunities and the stimulus package dummy. As for the variables of both Bankdummy*RET*Stimulus and Bankshare*RET*Stimulus, we find statistically negative coefficients for the SOE subsample, and positive coefficients for the non-SOE subsample. For example, in columns 3 and 5 the coefficients on Bankdummy*RET*Stimulus are -0.02 and 0.03 for SOEs and non-SOEs, respectively, both of which are significant at the 5\% level (t-values are -2.25 and 2.06, respectively). These results indicate that dual holding weakens the investment efficiency of SOEs while enhancing the investment efficiency for non-SOEs, and that these effects are reinforced with the introduction of the economic stimulus package. Overall, the results from Table 12 are consistent with the results from Tables 6 and 7, which confirms that our results are robust after taking the endogeneity issue into account by applying a natural experiment.

Table 12. Impact of dual holding on lending decisions and investment efficiency: natural experiment

\begin{tabular}{|c|c|c|c|c|c|c|}
\hline & \multicolumn{2}{|c|}{ Full sample } & \multicolumn{2}{|c|}{ SOE subsample } & \multicolumn{2}{|c|}{ Non-SOE subsample } \\
\hline \multicolumn{7}{|c|}{ Panel A: Bank lending decisions regression } \\
\hline Bankdummy & $\begin{array}{l}0.03 \\
(1.24)\end{array}$ & & $\begin{array}{l}0.03 \\
(0.69)\end{array}$ & & $\begin{array}{l}0.04^{* *} \\
(1.98)\end{array}$ & \\
\hline Bankdummy*ROS & $\begin{array}{l}-0.03 \\
(-0.29)\end{array}$ & & $\begin{array}{l}-0.09 \\
(-0.42)\end{array}$ & & $\begin{array}{l}0.08^{* *} \\
(2.49)\end{array}$ & \\
\hline Bankdummy*ROS*Stimulus & $\begin{array}{l}-0.02 \\
(-0.34)\end{array}$ & & $\begin{array}{l}-0.02^{* *} \\
(-2.23)\end{array}$ & & $\begin{array}{l}0.14 \\
(1.38)\end{array}$ & \\
\hline Bankshare & & $\begin{array}{l}0.06 \\
(1.27)\end{array}$ & & $\begin{array}{l}0.03 \\
(0.75)\end{array}$ & & $\begin{array}{l}0.07 * * \\
(2.55)\end{array}$ \\
\hline Bankshare*ROS & & $\begin{array}{l}-0.03 \\
(-1.34)\end{array}$ & & $\begin{array}{l}-0.04^{* *} \\
(-1.99)\end{array}$ & & $\begin{array}{l}0.02 * \\
(1.89)\end{array}$ \\
\hline Bankshare*ROS*Stimulus & & $\begin{array}{l}-0.03 \\
(-1.39)\end{array}$ & & $\begin{array}{l}-0.03 * \\
(-1.92)\end{array}$ & & $\begin{array}{l}0.02 * * \\
(2.05)\end{array}$ \\
\hline
\end{tabular}

Other control variables include Stimulus, ROS, ROS*Stimulus, Bank dual holding and Stimulus interactions, firm size, tangible assets, political connection, board size, independent director ratio, lagged loan level, bankfirm relationship, and industry fixed effects.

\begin{tabular}{lllllll} 
Adjusted R & & & & \\
Observations & 0.013 & 0.13 & 0.13 & 0.14 & 0.14 & 0.13 \\
\multicolumn{2}{l}{ Panel B: Firm investment efficiency regression } & & & & \\
\hline Bankdummy & $0.05^{* * *}$ & & $0.08^{* *}$ & & $0.04^{* *}$ & \\
& $(2.71)$ & & $(2.08)$ & & $(2.26)$ & \\
Bankdummy*RET & -0.08 & & -0.03 & & $0.09^{* *}$ & \\
& $(-0.51)$ & & $(-0.17)$ & & $(2.43)$ & \\
Bankdummy*RET*Stimulus & $-0.02^{*}$ & & $-0.02^{* *}$ & & $0.03^{* *}$ & \\
& $(-1.71)$ & & $(-2.25)$ & & $(2.06)$ & \\
Bankshare & & $0.08^{* * *}$ & & $0.12^{* *}$ & & $0.07^{* * *}$ \\
& & $(2.61)$ & & $(2.40)$ & & $(2.59)$
\end{tabular}




$\begin{array}{llll}\text { Bankshare*RET } & -0.01 & -0.01^{* *} & 0.01^{* *} \\ \text { Bankshare*RET*Stimulus } & (-0.39) & (-2.23) & (2.37) \\ & -0.02 & -0.03 * * * & 0.01^{* *} \\ & (-1.39) & (-2.60) & (2.40)\end{array}$

Other control variables include Stimulus, RET, RET*Stimulus, Bank dual holding and Stimulus interactions, leverage, income, firm size, sales, tangible assets, and industry fixed effects.

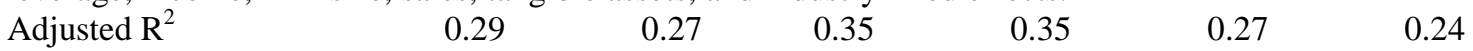

$\begin{array}{lllllll}\text { Observations } & 7420 & 7420 & 5077 & 5077 & 2343 & 2343\end{array}$

This table reports the regression results using the natural experiment method to address the endogeneity issue of dual holding. Package is a dummy variable equal to 1 for firm-year observations falling during the posteconomic stimulus package period. All the variables are defined as in previous tables.

The T-statistics are in parentheses, and were computed using the White (1980) heteroscedasticity robust standard error, clustered by firm; *, **, and *** indicate the significance levels at $10 \%, 5 \%$, and $1 \%$, respectively.

\subsubsection{Two-stage least square and firm fixed-effect regression}

In this section, we apply the two-stage least square (2SLS) approach to address the endogeneity issue. Following Luo et al. (2011) we choose the number of employees of the firm as the instrumental variable of dual holding. In the first stage we regress dual holding against the instrumental variable as well as a set of control variables, and in the second stage we use the predicted value of dual holding obtained from the first stage as a proxy for dual holding in the bank-loan and investment equation. The results of using 2SLS for banks' lending decisions and firms' investment efficiencies are reported in Tables 13 and 14, respectively. From Panel A in both tables, we observe that number of employees is positively and significantly related to dual holding in the first stage. From the results of the second stages (Panel B in both tables), we observe a similar sign and significance of estimated coefficients of our key variables to those reported in Tables 6 and 7.

Table 13. 2SLS estimation of bank lending decision regression

\begin{tabular}{lcccccc}
\hline \multicolumn{2}{c}{ Full sample } & \multicolumn{2}{c}{ SOE subsample } & \multicolumn{2}{c}{ Non-SOE subsample } \\
\hline \multicolumn{2}{l}{ Panel A: First stage, where bank dual holding is the dependent variable } & & \\
\hline Employee & $0.13^{* *}$ & $0.02^{* * *}$ & $0.05^{* *}$ & $0.02^{*}$ & $0.34^{* *}$ & $0.03^{* *}$ \\
& $(2.49)$ & $(2.65)$ & $(2.50)$ & $(1.72)$ & $(2.20)$ & $(2.09)$
\end{tabular}
tangible assets, return on sales, political connection, lagged loan level, bank-firm relationship, and year and industry fixed effects.

\begin{tabular}{|c|c|c|c|c|c|c|}
\hline Adjusted $\mathrm{R}^{2}$ & 0.02 & 0.10 & 0.01 & 0.08 & 0.04 & 0.18 \\
\hline Observations & 7420 & 7420 & 5077 & 5077 & 2343 & 2343 \\
\hline \multicolumn{7}{|c|}{ Panel B: Second stage, where change in bank loan is the dependent variable } \\
\hline Bankdummy & $0.23 * * *$ & & $0.22 * *$ & & $0.23 * *$ & \\
\hline & $(2.66)$ & & $(2.17)$ & & $(2.06)$ & \\
\hline Bankdummy*ROS & $\begin{array}{l}-0.16^{* * *} \\
(-3.49)\end{array}$ & & $\begin{array}{l}-0.22 * * * \\
(-2.71)\end{array}$ & & $\begin{array}{l}0.18^{* *} \\
(2.32)\end{array}$ & \\
\hline Bankshare & & $\begin{array}{l}0.15^{* *} \\
(2.02)\end{array}$ & & $\begin{array}{l}0.15^{*} \\
(1.65)\end{array}$ & & $\begin{array}{l}0.12^{* *} \\
(2.24)\end{array}$ \\
\hline Bankshare*ROS & & $\begin{array}{l}-0.02 \\
(-0.37)\end{array}$ & & $\begin{array}{l}-0.02^{* *} \\
(-2.30)\end{array}$ & & $\begin{array}{l}0.01^{*} \\
(1.93)\end{array}$ \\
\hline
\end{tabular}

Other variables are also included in the second stage regression: return on sales, firm size, tangible assets, board size, independent director ratio, political connection, lagged loan level, bank-firm relationship, and year and industry fixed effects. 


\begin{tabular}{|c|c|c|c|c|c|c|}
\hline Adjusted $\mathrm{R}^{2}$ & 0.10 & 0.08 & 0.08 & 0.10 & 0.16 & 0.08 \\
\hline Observations & 7420 & 7420 & 5077 & 5077 & 2343 & 2343 \\
\hline
\end{tabular}

This table reports both the first- and second-stage regression results of the bank lending decision equation. Employee is the log of the number of employees, which is used as the instrument variable of dual holding in the first stage. The definitions of other variables are the same as those in previous tables.

The T-statistics are in parentheses, and were computed using the White (1980) heteroscedasticity robust standard error, clustered by firm; *, **, and *** indicate the significance levels at $10 \%, 5 \%$, and $1 \%$, respectively.

Table 14. 2SLS estimation of firm investment efficiency regression

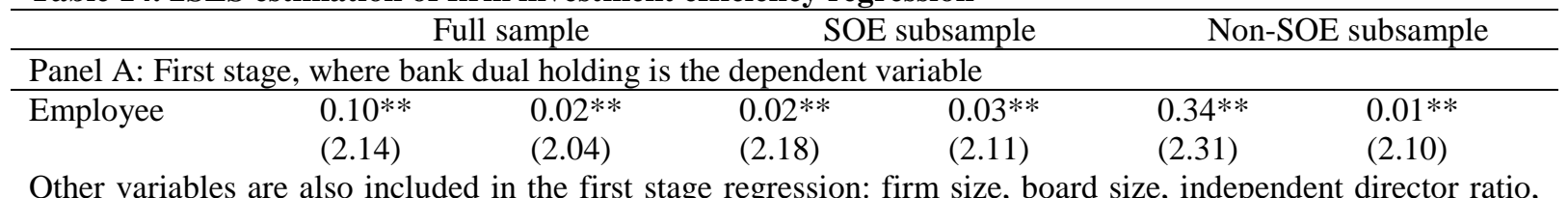
tangible assets, leverage, net income, sales, change in investment opportunities, and year and industry fixed effects.

\begin{tabular}{|c|c|c|c|c|c|c|}
\hline Adjusted $\mathrm{R}^{2}$ & 0.12 & 0.40 & 0.08 & 0.63 & 0.31 & 0.37 \\
\hline Observations & 7420 & 7420 & 5077 & 5077 & 2343 & 2343 \\
\hline \multicolumn{7}{|c|}{ Panel B: Second stage, where the log of the investment growth is the dependent variable } \\
\hline Bankdummy & $\begin{array}{l}0.37^{*} \\
(1.70)\end{array}$ & & $\begin{array}{l}0.07 * * \\
(2.33)\end{array}$ & & $\begin{array}{l}0.50^{* *} \\
(2.27)\end{array}$ & \\
\hline Bankdummy*RET & $\begin{array}{l}-0.32 \\
(-1.08)\end{array}$ & & $\begin{array}{l}-0.57 * * \\
(-2.55)\end{array}$ & & $\begin{array}{l}0.37^{* * *} \\
(2.59)\end{array}$ & \\
\hline Bankshare & & $\begin{array}{l}0.28^{* *} \\
(2.42)\end{array}$ & & $\begin{array}{l}0.19 * * * \\
(2.62)\end{array}$ & & $\begin{array}{l}0.34^{* *} \\
(2.22)\end{array}$ \\
\hline Bankshare*RET & & $\begin{array}{l}-0.06 \\
(-1.63)\end{array}$ & & $\begin{array}{l}-0.15 * * \\
(-1.96)\end{array}$ & & $\begin{array}{l}0.08^{*} \\
(1.81)\end{array}$ \\
\hline
\end{tabular}

Other variables are also included in the second stage regression: RET, firm size, tangible assets, leverage, board size, independent director ratio, net income, sales, change in investment opportunities, and year and industry fixed effects.

\begin{tabular}{|c|c|c|c|c|c|c|}
\hline Adjusted $\mathrm{R}^{2}$ & 0.27 & 0.29 & 0.33 & 0.24 & 0.27 & 0.32 \\
\hline Observations & 7420 & 7420 & 5077 & 5077 & 2343 & 2343 \\
\hline
\end{tabular}

This table reports both the first- and second-stage regression results of the firm investment efficiency equation. Employee is the log of the number of employees, which is used as the instrument variable of dual holding in the first stage. The definitions of other variables are the same as those in previous tables.

The T-statistics are in parentheses, and were computed using the White (1980) heteroscedasticity robust standard error, clustered by firm; *, **, and *** indicate the significance levels at $10 \%$, 5\%, and $1 \%$, respectively.

Moreover, we also apply the fixed-effect regression to further check the robustness of our results. Following the discussion by Lang et al. (1996), Aivazian et al. (2005), and Firth et al. (2008), we use the firm fixed-effect panel data regression to mitigate the unobservable time-invariant firm effect. The results of using the firm fixed effect are reported in Table 15. The results for our key variables are broadly similar to those reported in Tables 6 and 7. Overall, putting the results of both 2SLS and firm fixed effect regression together, our main findings are valid that dual holding improves bank lending and enhances investment efficiency for non-SOEs, while the opposite is true for SOEs.

Table 15. Firm fixed-effect estimation

\begin{tabular}{lcc}
\hline \multicolumn{1}{c}{ Full sample } & SOE subsample & Non-SOE subsample \\
\hline Panel A: Bank lending decision equation & & \\
\hline Bankdummy $0.11^{*}$ & 0.05 & $0.25^{*}$ \\
\hline
\end{tabular}




\begin{tabular}{|c|c|c|c|c|c|c|}
\hline & $(1.75)$ & & $(0.72)$ & & $(1.80)$ & \\
\hline Bankdummy*ROS & $\begin{array}{l}-0.03^{* *} \\
(-2.40)\end{array}$ & & $\begin{array}{l}-0.03^{* *} \\
(-1.99)\end{array}$ & & $\begin{array}{l}0.02^{* *} \\
(2.08)\end{array}$ & \\
\hline Bankshare & & $\begin{array}{l}0.05^{* *} \\
(2.27)\end{array}$ & & $\begin{array}{l}0.05 \\
(0.28)\end{array}$ & & $\begin{array}{l}0.05^{* *} \\
(2.16)\end{array}$ \\
\hline Bankshare*ROS & & $\begin{array}{l}-0.03 * * \\
(-2.38)\end{array}$ & & $\begin{array}{l}-0.03 * * \\
(-1.99)\end{array}$ & & $\begin{array}{l}0.02 * \\
(1.92)\end{array}$ \\
\hline
\end{tabular}

Other variables included in this regression include: return on sales, firm size, tangible assets, board size, independent director ratio, political connection, lagged loan level, and bank-firm relationship.

\begin{tabular}{|c|c|c|c|c|c|c|}
\hline Adjusted $\mathrm{R}^{2}$ & 0.18 & 0.08 & 0.17 & 0.08 & 0.25 & 0.07 \\
\hline Observations & 7420 & 7420 & 5077 & 5077 & 2343 & 2343 \\
\hline \multicolumn{7}{|c|}{ Panel B: Firm investment efficiency equation } \\
\hline \multirow[t]{2}{*}{ Bankdummy } & $0.03^{* *}$ & & $0.04 *$ & & $0.03 * *$ & \\
\hline & (2.11) & & (1.74) & & (2.43) & \\
\hline \multirow[t]{2}{*}{ Bankdummy*RET } & -0.02 & & $0.02 *$ & & $0.03^{* *}$ & \\
\hline & $(-1.13)$ & & (1.88) & & $(2.07)$ & \\
\hline \multirow[t]{2}{*}{ Bankshare } & & $0.26 * *$ & & $0.39 *$ & & $0.10 * *$ \\
\hline & & $(2.02)$ & & $(1.86)$ & & $(2.07)$ \\
\hline \multirow[t]{2}{*}{ Bankshare*RET } & & $-0.02 *$ & & $-0.03 *$ & & $0.01 * *$ \\
\hline & & $(-1.75)$ & & $(-1.85)$ & & $(2.10)$ \\
\hline
\end{tabular}

Other variables included in this regression include: firm size, tangible assets, leverage, board size, independent director ratio, net income, sales, and change in investment opportunities.

$\begin{array}{lllllll}\text { Adjusted } \mathrm{R}^{2} & 0.15 & 0.11 & 0.18 & 0.15 & 0.08 & 0.08 \\ \text { Observations } & 7420 & 7420 & 5077 & 5077 & 2343 & 2343\end{array}$

This table reports the firm fixed effect of determinants of the change in bank loans and investment growth for the full sample, SOE sub-sample, and non-SOE sub-sample. The definitions of all variables are the same as those in previous tables.

The T-statistics are in parentheses, and were computed using the White (1980) heteroscedasticity robust standard error, clustered by firm; *, **, and *** indicate the significance levels at $10 \%, 5 \%$, and $1 \%$, respectively.

\subsection{Further analysis: Dual holding and firm performance}

Our findings suggest that dual holding affects banks' lending decisions and firms' investment behaviour differently in SOEs and non-SOEs. Because this study has proposed that dual holders' lending decisions affect firms' investment policies, and it is the mechanism through which dual holding affects firm performance, it has been interesting to explore whether dual holding influences firm performance in the same way as it influences lending and investment. To test our additional hypothesis we conduct the following equation:

$$
\begin{aligned}
\text { Performance }_{i t}= & \alpha_{0}+\alpha_{1} \text { Bank }_{i t-1}+\alpha_{2} \text { Bank }_{i t-1} * \text { Investment }_{i t}+\alpha_{3} \text { Investment }_{i t} \\
& +\alpha_{4} \text { Size }_{i t}+\alpha_{5} \text { Leverage }_{i t}+\alpha_{6} \text { Largest }_{i t}+\alpha_{7} \text { Board }_{i t} \\
& +\alpha_{8} \text { Indep }_{i t}+\varepsilon_{i t}
\end{aligned}
$$

where Performance is the measure of firm performance. We apply return on assets (ROA) as a proxy for firm performance. All the other variables are defined as in previous tables. The regression results are reported in Table 16. We assume that firm investment is determined by a set of variables that are also included in Equation (3); thus our regression suffers from an endogenous issue. To address this issue we apply the 2SLS method and choose the regional index as the instrumental variable, following Fan et al. (2011). In the first stage we regress 
firm investment expenditures against the regional index and a set of control variables. In the second stage the value of investment is the predicted value obtained from the first stage. We report the results for the first and second stages in Table 16.

In Panel A, we find that the regional index is positively related to firm investment expenditures, which indicates that the average investment level of a firm is significantly higher in the area with better development. In Panel B we find evidence supporting our hypothesis that dual holding affects firm performance through investment policy differently in SOEs and non-SOEs. For the full sample we find that both dual holding and the interaction term between dual holding and investment are negatively related to firm performance, which is consistent with the previous evidence in emerging markets (Fok et al., 2004; Lin et al., 2009). However, we are curious about the dual holding effect on firm performance, so we rerun the regression for both SOE and non-SOE subsamples respectively and report the results in columns 3 to 6 . In particular, we observe that dual holding has a negative effect on firm performance for SOEs. When we combine the net effect of Bankdummy*PInvestment and PInvestment, we find that investment is negatively related to firm performance for SOEs. For example, in column 3 the estimated coefficients on Bankdummy*PInvestment and PInvestment are -0.31 and 0.26 , significant at the $5 \%$ and $10 \%$ levels (t-values are -2.49 and 1.94), and the net effect is negative $(-0.31+0.26=-0.05)$, whereas the opposite effect occurs in the non-SOE subsample. For instance, in column 5 the estimated coefficients on Bankdummy*PInvestment and PInvestment are 0.10 and 0.17 , both of which are significant at the $5 \%$ level (t-values are 2.33 and 2.03), and the net effect is positive $(0.10+0.17=0.27)$, indicating that investment is positively related to firm performance for non-SOEs. Furthermore, a similar effect occurs when we apply the percentage of shares held by bank shareholders as the measure of dual holding. Among the control variables, we find that ownership of the largest shareholder is positively associated with firm performance, which is consistent with the arguments of Shleifer and Vishny (1986). The positive relationship in SOEs seems to be in contrast to previous evidence from China. This may be because we use the total equity shares held by the largest shareholders, rather than only the legal-person shares held by the largest shareholders, as in previous studies (Qi et al., 2000). In general, our results suggest that dual holding has a negative effect on firm performance in SOEs and a positive effect on firm performance in non-SOEs. As a robustness check, we rerun our Equation (4) with different proxies for firm performance, including return on sales (ROS) and Tobin's Q (Q), and find similar results to those in Table 16. Overall, our study suggests that dual holding helps SOEs obtain easier access to bank loans but does not exert enough 
monitoring over their loans or how they are used. However, in non-SOEs dual holding is more likely to exercise monitoring functions, which improves firm performance. We argue that whether dual holding is positively related to firm performance depends on a firm's investment policy.

Table 16. The effect of dual holding on firm performance: 2SLS method

\begin{tabular}{|c|c|c|c|c|c|c|}
\hline & $\mathrm{Fu}$ & mple & & & & SOEs \\
\hline Panel A: The results for the & first stage, & re depende & variable is & estment ex & nditures & \\
\hline Bankdummy & $0.04^{* *}$ & & $0.02 *$ & & $0.08 * *$ & \\
\hline & $(2.29)$ & & (1.95) & & (2.69) & \\
\hline Bankshare & & $0.10^{*}$ & & 0.07 & & $0.14^{* *}$ \\
\hline & & (1.95) & & (1.11) & & $(1.96)$ \\
\hline Q & $0.07 *$ & $0.06^{*}$ & $0.05 *$ & $0.05 *$ & $0.10 * * *$ & $0.10 * * *$ \\
\hline & $(1.91)$ & $(1.90)$ & $(1.75)$ & (1.73) & $(2.58)$ & $(2.57)$ \\
\hline Leverage & $-0.12 * * *$ & $-0.10^{* *}$ & -0.03 & -0.04 & $-0.52 * *$ & $-0.53^{* *}$ \\
\hline & $(-2.22)$ & $(-2.19)$ & $(-0.13)$ & $(-0.15)$ & $(-2.29)$ & $(-2.30)$ \\
\hline Income & 0.06 & 0.07 & 0.38 & 0.40 & 0.01 & 0.01 \\
\hline & $(0.01)$ & $(0.06)$ & $(1.15)$ & $(1.20)$ & $(0.33)$ & $(0.34)$ \\
\hline Size & 0.09 & 0.08 & $0.09 * * *$ & $0.09 * * *$ & 0.07 & 0.07 \\
\hline & $(1.51)$ & (1.48) & (2.69) & $(2.68)$ & $(0.35)$ & $(0.35)$ \\
\hline Sale & $-0.10 * *$ & $-0.11^{* *}$ & $-0.12 * *$ & $-0.12 * *$ & -0.02 & -0.02 \\
\hline & $(-1.97)$ & $(-2.07)$ & $(-2.21)$ & $(-2.21)$ & $(-0.04)$ & $(--0.04)$ \\
\hline Tangibility & $0.35 * *$ & $0.35^{* *}$ & $0.29 * * *$ & $0.29 * * *$ & $0.39 *$ & $0.38 *$ \\
\hline & (1.99) & $(2.01)$ & (3.08) & $(3.08)$ & (1.71) & (1.70) \\
\hline Largest & -0.02 & -0.02 & $-0.03^{*}$ & $-0.03^{*}$ & -0.00 & -0.01 \\
\hline & $(-1.35)$ & $(-1.38)$ & $(-1.76)$ & $(-1.77)$ & $(-0.04)$ & $(-0.04)$ \\
\hline Board & -0.08 & -0.09 & -0.05 & -0.06 & -0.09 & -0.09 \\
\hline & $(-0.69)$ & $(-0.69)$ & $(-0.56)$ & $(-0.56)$ & $(-0.22)$ & $(-0.22)$ \\
\hline Indep & -0.30 & -0.29 & -0.08 & -0.08 & -0.60 & -0.60 \\
\hline & $(-1.57)$ & $(-1.56)$ & $(-0.49)$ & $(-0.47)$ & $(-1.41)$ & $(-1.41)$ \\
\hline Regional index & $0.16 * * *$ & $0.16 * * *$ & $0.26 * *$ & $0.25 * *$ & $0.05^{* *}$ & $0.05^{* *}$ \\
\hline & $(2.92)$ & $(2.90)$ & $(2.21)$ & (2.19) & $(2.06)$ & $(2.04)$ \\
\hline Constant & -0.87 & -0.85 & -1.09 & -1.07 & -0.26 & -0.28 \\
\hline & $(-0.59)$ & $(-0.57)$ & $(-1.32)$ & $(-1.30)$ & $(-0.05)$ & $(-0.05)$ \\
\hline Year fixed effects & Included & Included & Included & Included & Included & Included \\
\hline Industry fixed effects & Included & Included & Included & Included & Included & Included \\
\hline Adjusted $\mathrm{R}^{2}$ & 0.32 & 0.31 & 0.34 & 0.32 & 0.26 & 0.29 \\
\hline Observations & 7420 & 7420 & 5077 & 5077 & 2343 & 2343 \\
\hline Panel B: The results for the & second stag & here deper & nt variable & irm perfor & ance & \\
\hline Bankdummy & $-0.02 * *$ & & $-0.02 * *$ & & $0.01 * *$ & \\
\hline & $(-2.22)$ & & $(-2.29)$ & & $(2.64)$ & \\
\hline Bankdummy*PInvestment & $-0.26 * *$ & & $-0.31 * *$ & & $0.10^{* *}$ & \\
\hline & $(-2.08)$ & & $(-2.49)$ & & $(2.33)$ & \\
\hline Bankshare & & $-0.26 * * *$ & & $-0.27 * * *$ & & $0.01 *$ \\
\hline & & $(-3.75)$ & & $(-3.44)$ & & $(1.85)$ \\
\hline Bankshare*PInvestment & & $-0.28 *$ & & $-0.32 * *$ & & $0.02^{* *}$ \\
\hline & & $(-1.65)$ & & $(-2.09)$ & & (2.38) \\
\hline PInvestment & $0.22 * * *$ & $0.23 * * *$ & $0.26 *$ & $0.28 *$ & $0.17^{* *}$ & $0.17 * *$ \\
\hline & (3.15) & (3.30) & $(1.94)$ & $(1.72)$ & (2.03) & $(2.01)$ \\
\hline Size & $0.03 * * *$ & $0.02 * * *$ & $0.02 * * *$ & $0.02 * * *$ & $0.03 * * *$ & $0.03^{* * *}$ \\
\hline & (14.49) & $(14.45)$ & (12.58) & (12.56) & (8.98) & $(9.01)$ \\
\hline Leverage & $-0.20 * * *$ & $-0.20 * * *$ & $-0.17 * * *$ & $-0.17 * * *$ & $-0.22 * * *$ & $-0.22 * * *$ \\
\hline & $(-12.47)$ & $(-12.45)$ & $(-11.96)$ & $(-11.74)$ & $(-6.23)$ & $(-6.24)$ \\
\hline Largest & $0.02 * * *$ & $0.02 * * *$ & $0.02 * * *$ & $0.02 * * *$ & $0.02 * *$ & $0.02 * *$ \\
\hline & $(4.46)$ & $(4.45)$ & (3.29) & (3.25) & $(2.11)$ & (2.08) \\
\hline Board & 0.03 & 0.03 & 0.06 & 0.05 & 0.04 & 0.05 \\
\hline & $(0.81)$ & $(0.84)$ & (1.15) & (1.15) & $(0.50)$ & $(0.60)$ \\
\hline Indpe & 0.05 & 0.06 & 0.04 & 0.05 & 0.04 & 0.04 \\
\hline
\end{tabular}




\begin{tabular}{lllllll}
\hline & $(0.77)$ & $(0.82)$ & $(0.47)$ & $(0.55)$ & $(0.34)$ & $(0.35)$ \\
Constant & $-0.37^{* * *}$ & $-0.37^{* * *}$ & $-0.33^{* * *}$ & $-0.32^{* * *}$ & $-0.56^{* * *}$ & $-0.56^{* * *}$ \\
& $(-12.46)$ & $(-12.38)$ & $(-10.31)$ & $(-10.19)$ & $(-8.28)$ & $(-8.31)$ \\
Year fixed effects & Included & Included & Included & Included & Included & Included \\
Industry fixed effects & Included & Included & Included & Included & Included & Included \\
Adjusted R & 0.33 & 0.33 & 0.26 & 0.25 & 0.42 & 0.42 \\
Observations & 7420 & 7420 & 5077 & 5077 & 2343 & 2343 \\
\hline
\end{tabular}

This table reports the results of estimating firm performance against dual holding and other control variables. Panel A reports the first stage results, where the dependent variable is firm investment. Regional index is the index compiled by Fan et al. (2011) as the proxy for regional development. Panel B reports the second stage results, where the dependent variable is firm performance, measured as return on assets (ROA). PInvestment is the predicted value of firm investment obtained from the first stage. Largest is the percentage of shares held by the largest shareholder. Board is the log of number of director on the boards. Indep is the percentage of independent directors to total number of directors on the boards. All the other variables are defined as in previous tables.

The T-statistics are in parentheses, and were computed using the White (1980) heteroscedasticity robust standard error, clustered by firm; *, **, and *** indicate the significance levels at $10 \%, 5 \%$, and $1 \%$, respectively.

\section{Conclusion}

The objective of this paper is to examine the financial implications of dual holding on banks' lending decisions and firms' investment efficiency. We are motivated by the mixed evidence that exists about how dual holding affects firm performance, so we dig deeper to investigate the mechanism through which dual holding influences firm performance, in order to explain why the existing evidence is mixed. We find that the potential collusion between managers of banks and firms arising from dual holding affects banks' lending decisions and firms' investment policy, which results in the different effects that dual holding has on firm performance. We use data from China's listed firms and find that the presence of banks' dual holding results in easier access to bank loans, and in particular long-term bank loans, effects that are more pronounced in non-SOEs. Moreover, dual holding distorts banks' lending decisions and weakens firms' investment efficiencies for SOEs, while enhancing lending and investment efficiencies for non-SOEs.

Our results also provide evidence to support our hypothesis that in non-SOEs the higher ownership concentration of the controlling shareholders is more effective in preventing firms' executives from colluding with bank managers. Our results also show that among all types of ultimate owners, family owners and foreign investors are more likely to exert effective monitoring than other types of ultimate owners. Further analysis suggests that whether dual holding can increase firm performance depends largely on whether investment is efficient, which is also influenced by banks' lending decisions. We also provide evidence that the economic stimulus package has further distorted economic efficiency in SOEs, with our results showing that low bank lending and investment efficiencies in SOEs with dual holding are exacerbated by government intervention, an effect that turns out to be positive for non- 
SOEs. Our main findings are robust to corrections for endogeneity of dual holding, including using single loan-contracts, event studies of announcements of loan contracts and mergers and acquisitions, the natural experiment of the economic stimulus package, and two-stage regressions.

Overall, we find that dual holding enables banks to extend more efficient loans to nonSOEs based on their commercial judgment, which leads to an efficient investment and adds value to non-SOEs. Conversely, dual holding distorts banks' lending decisions and investment efficiencies and destroys firm value for SOEs. We argue that in emerging markets whether a bank plays a monitoring role by directly holding the debt and equity claims of companies relies heavily on whether the potential collusion between managers of firms and banks can be averted; this in turn is determined by the firms' governance framework and ownership structure. 


\section{References:}

Allen, F., Qian, J., Qian, M., 2005. Law, finance, and economic growth in China. Journal of Financial Economics 77, 57-116.

Aivazian, V., Ge, Y., Qiu, J., 2005. The impact of leverage on firm investment: Canadian evidence. Journal of Corporate Finance 11, 277-291.

Almazan, A., Hartzell, J., Starks, L., 2005. Active institutional shareholders and costs of monitoring: Evidence from executive compensation. Financial Management 34(4), 5-34.

Barth, J., Caprio, G., Levine, R., 2006. Rethinking bank regulation: Till angels govern. Cambridge University Press.

Berger, A., N., Hasan, I., Zhou, M., 2009. Bank ownership and efficiency in China: What will happen in the world's largest nation? Journal of Banking and Finance 33, 113-130.

Bertrand, M., Schoar, A., Thesmar, D., 2007. Banking deregulation and industry structure: evidence from the French banking reforms of 1985. Journal of Finance 62(2), 597-628.

Bhagat, S., Romano, R., 2007. Empirical studies of corporate law. Handbook of Law and Economics 2, 945-1012.

Bharath, S.T., Dahiya, S., Saunders, A., Srinivasan, A., 2011. Lending relationships and loan contract terms. Review of Financial Studies 24(4), 1141-1203.

Boot, A. W. A., 2000. Relationship banking: What do we know? Journal of Financial Intermediation 9, 7-25.

Bushman, M. R., Piotroski, J. D., Smith, A. J., 2011. Capital allocation and timely accounting recognition of economic losses. Journal of Business Finance Accounting 38(1), 1-33.

Byrd, D. T., Mizruchi, M. S., 2005. Bankers on the board and the debt ratio of firms. Journal of Corporate Finance 11, 1129-173.

Cai, H., Fang, H., Xu, L., 2011. Eat, drink, firms, government: an investigation of corruption from the entertainment and travel costs of Chinese firms. Journal of Law and Economics 54(1), 55-78.

Cao, F., 2008. Monetary and Financial Management. Peking University Press. (Chinese)

Chen, G., Firth, M., Xu, L., 2009. Does the type of ownership control matter? Evidence from China’s listed companies. Journal of Banking and Finance 33, 171-181.

Chen, X., Harford, J., and Li, K., 2007. Monitoring: Which institutions matter? Journal of Financial Economics 86, 279-305.

Chen. S, Sun, Z., Tang, S., Wu, D., 2011. Government intervention and investment efficiency: Evidence from China. Journal of Corporate Finance 17, 259-271. 
Chen, Y., Liu, M., Su, J., 2013. Greasing the wheels of bank lending: Evidence from private firms in China. Journal of Banking and Finance 37(7), 2533-2545.

Cull, R., Xu, L., 2000. Bureaucrats, state banks, and the efficiency of credit allocation: the experience of Chinese state-owned enterprises. Journal of Comparative Economics 28, 1-41.

Cull, R., Xu, L., 2003. Who gets credit? The behaviour of bureaucrats and state banks in allocating credit to Chinese state-owned enterprises. Journal of Development Economics 71, 533-559.

Cull, R., Xu, L., 2005. Institutions, ownership, and finance: the determinants of profit reinvestment among Chinese firms. Journal of Financial Economics 77(1), 117-146.

Datta, S., Datta, M. I., Patel, A., 1999. Bank monitoring and the pricing of corporate public debt. Journal of Financial Economics 51, 435-449.

Diamond, D., 1984. Financial intermediation and delegated monitoring. Review of Economic Studies 51 (2), 393-414.

Douma, S., George, R., Kabir, R., 2006. Foreign and domestic ownership, business groups and firm performance: evidence from a large emerging market. Strategic Management Journal 27(7), 637-657.

Engelberg, J., Gao, P., Parsons, C. A., 2012. Friends with money. Journal of Financial Economics 103, 169-188.

Fama, E., 1985. What's different about banks? Journal of Monetary Economics 15, 29-39.

Fama, E. F., French, K. R., 1998. Taxes, financing decisions, and firm value. Journal of Finance 53(3), 819-843.

Fan, G., Wang, X., Zhu, H., 2011. The marketization index of China: The process of regional marketization report 2011. Beijing: Economic Science Press.

Fan, J. P. H., Rui, M., Zhao, M., 2008. Public governance and corporate finance: Evidence from corruption cases. Journal of Comparative Economics 36, 343-364.

Firth, M., Lin, C., Wong, S. M. L., 2008. Leverage and investment under a state-owned bank lending environment: Evidence from China. Journal of Corporate Finance 14, 642-653.

Firth, M., Lin, C., Liu, P., Wong, S. M. L., 2009. Inside the black box: Bank credit allocation in China’s private sector. Journal of Banking and Finance 33, 1144-1155.

Firth, M., Malatesta, P. H., Xin, Q., Xu, L., 2012. Corporate investment, government control, and financing channels: Evidence from China's listed companies. Journal of Corporate Finance 18, 433-450.

Fok, R., Chang, Y.-C., Lee,W.-T., 2004. Bank relationships and their effects on firm performance around the Asian financial crisis. Financial Management, 89-112. 
Guedes, J., Opler, T., 1996. The determinants of the maturity of corporate debt issues. Journal of Finance 51(5), 1809-1833.

Harvey, C. R., Lins, K. V., Roper, A. H., 2004. The effect of capital structure when expected agency costs are extreme. Journal of Financial Economics 74(1), 3-30.

Huang, W., Schwienbacher, A., Zhao, S., 2012. When bank loans are bad news: Evidence from market reactions to loan announcements under the risk of expropriation. Journal of International Financial Market, Institutions \& Money 22, 233-252.

Jensen, M. C., Meckling. W. H., 1976. Theory of the firm: Managerial behaviour, agency costs, and ownership structure. Journal of Financial Economics 3, 305-360.

Jiang, W., Li, K., Shao, P., 2010. When shareholders are creditors: Effects of the simultaneous holding of equity and debt by non-commercial banking institutions. Review of Financial Studies 23(10), 3595-3637.

Kang, J.-K., Shivdasani, A., 1995. Firm performance, corporate governance and top executive turnovers in Japan. Journal of Financial Economics 38, 29-58.

Kang, J.-K., Shivdasani, A., Yamada, T., 2000. The effect of bank relations on investment decisions: an investigation of Japanese takeover bids. Journal of Finance, 2197-2218.

Kroszner, R.S., Strahan, P.E., 2001. Bankers on boards: monitoring, conflicts of interest, and lender liability. Journal of Financial Economics 62, 415-452.

La Porta, R., Lopez-de-Silanes, F., Shleifer, A., 1999. Corporate ownership around the world. Journal of Finance 54(2), 471-517.

Lang, L., Ofek, E., Stulz, R., 1996. Leverage, investment and firm growth. Journal of Financial Economics 40, 3-29.

Lin, X., Zhang, Y., Zhu, N., 2009. Does bank ownership increase firm value? Evidence from China. Journal of International Money and Finance 28, 720-737.

Luo, W., Zhang, Y., Zhu, N., 2011. Bank ownership and executive perquisites: New evidence from an emerging market. Journal of Corporate Finance 17, 352-370.

Mahrt-Smith, J., 2006. Should banks own equity stakes in their borrowers? A contractual solution to hold-up problems. Journal of Banking and Finance 30, 2911-2929.

Myers, S. C., 1977. The determinants of corporate borrowing. Journal of Financial Economics 5, 147-175.

Onaran, Y., 2013. Bad loans could spark an emerging-markets crisis. Bloomberg Businessweek, November 21.

Pindado, J., Requejo, I., Torre, C., 2011. Family control and investment-cash flow sensitivity: Empirical evidence from the Euro zone. Journal of Corporate Finance 17, 1389-1409. 
Qi, D., W, Wu., Zhang,H., 2000. Shareholding structure and corporate performance of partially privatized firms: Evidence from listed Chinese companies. Pacific-Basin Finance Journal 8, 587-610.

Santos, J., Rumble, A.S., 2006. The American Keiretsu and universal banks: investing, voting and sitting on non-financials' corporate boards. Journal of Financial Economics 80, 419-454. Shen, J., Firth, M., Poon, W., 2014. Bank loan supply and corporate capital structure: recent evidence from China, Financial Management Association annual meeting, working paper.

Shleifer, A., and R. Vishny, 1986, Large shareholders and corporate control, Journal of Political Economy 94, 461-488.

Stulz, R. M., 1990. Managerial discretion and optimal financing policies. Journal of Financial Economics 26, 3-27.

Wang, R., 2012. Chinese culture and its potential influence on entrepreneurship. International Business Research 5(10), 76-90.

Wei, Z., Xie, F., Zhang, S., 2005. Ownership structure and firm value in China's privatized firms: 1991-2001. Journal of Financial and Quantitative Analysis 40(1), 87-108.

Welch, I., 1997. Why is bank debt senior? A theory of asymmetry and claim priority based on influence costs. Review of Financial Studies 10(4), 1203-1236.

White, H., 1980. A heteroskedasticity-consistent covariance matrix estimator and a direct test for heteroskedasticity. Econometrica 48(4), 817-838.

Zeng, Y., Yuan, Q., Zhang, J., 2011. Dark side of institutional shareholder activism in emerging markets: Evidence from China's split share structure reform. Asia-Pacific Journal of Financial Studies 40(2), 240-260.

Zheng, Y., Zhu, Y., 2013. Bank lending incentives and firm investment decisions in China. Journal of Multinational Financial Management 23, 146-165. 